\title{
Variation in the helminth community structure in spiny mice (Acomys dimidiatus) from four montane wadis in the St Katherine region of the Sinai Peninsula in Egypt
}

\author{
J. M. BEHNKE ${ }^{1 *}$, P. D. HARRIS ${ }^{1}$, A. BAJER ${ }^{2}$, C. J. BARNARD ${ }^{1}$, N. SHERIF ${ }^{3}$, L. CLIFFE ${ }^{1}$, \\ J. HURST ${ }^{1}$, M. LAMB ${ }^{1}$, A. RHODES ${ }^{1}$, M. JAMES ${ }^{1}$, S. CLIFFORD ${ }^{1}$, F. S. GILBERT ${ }^{1}$ \\ and S. ZALAT ${ }^{3}$ \\ ${ }^{1}$ School of Biology, University of Nottingham, University Park, Nottingham NG7 2RD, UK \\ ${ }^{2}$ Department of Parasitology, Institute of Zoology, University of Warszawa, ul. Miecznikowa 1, 02-096 Warszawa, Poland \\ ${ }^{3}$ Department of Zoology, Suez Canal University, Ismailia, Egypt
}

(Received 17 October 2003; revised 2 February 2004; accepted 3 February 2004)

\section{S U M M A R Y}

We compared helminth communities in spiny mice (Acomys dimidiatus) from 4 wadis in the arid montane region of the southern Sinai in Egypt, in a 4-week period in late summer. Total helminth species richness was 14 ( 8 nematodes, 5 cestodes and 1 acanthocephalan) with $94 \%$ of mice carrying at least 1 species and an overall mean species richness of $1 \cdot 85$. The most prevalent parasites were Protospirura muricola (47.8\%) and Dentostomella kuntzi (46.3\%). One larval cestode, Foyeuxiella rossicum, represents a new host record. The helminth community was dominated by intestinal nematodes $(88.7 \%)$ of which $58.2 \%$ were arthropod-transmitted heteroxenic species. At the component community level, $70 \%$ of the worms were recovered from mice in just two wadis (Gharaba and Tlah) and $48.6 \%$ of intestinal nematodes were from Wadi Gharaba. Although only 7 species of helminths were recorded from Wadi Gharaba, this site gave the highest Berger-Parker dominance index because P. muricola. P. muricola was also dominant in Wadi El Arbaein whilst Syphacia minuta was the dominant species in Wadis Gebal and Tlah. At the infracommunity level, mean species richness and Brillouin's index of diversity were highest in Wadi Tlah and lowest in Wadi Gebal, and the former was age dependent. Whilst mice from different wadis differed in the nematodes that were most common, those from Wadi Gharaba carried the highest mean number of worms/mouse. The abundance of $P$. muricola in particular varied markedly between sites: Wadi Gharaba was distinct as the site showing the highest mean worm burden whereas mice from Wadi Gebal were uninfected. None of the directly transmitted oxyuroid nematodes showed significant variation in abundance between wadis, or host sex or age classes. Overall, the single extrinsic factor in the study, site of capture, was more important than the intrinsic factors in explaining variation in helminth communities in the region. We conclude that in the high mountains of southern Sinai, each wadi is distinct in terms of its rodent parasites, and hence we expect spatially different coevolutionary pressures on their hosts, with resultant variation in life-histories.

Key words: spiny mouse, Acomys dimidiatus, helminths, nematodes, cestodes, acanthocephalans, component community, helminth diversity, site-specific variation.

\section{INTRODUCTION}

Human activities throughout the ages have led to dramatic alterations of the environment and the pace of the changes has never been as marked and rapid as in the 20th and 21st Centuries. Consequently there is much current concern over the resultant fragmentation of the environment by towns, major roads, agricultural activities etc. and in recent years the value and role of ecological corridors have been much-debated issues (Hanski, 1997; Gilbert, Gonzalez \& Evans-Freke, 1998). Fragmentation of the environment can also arise from natural barriers

* Corresponding author: School of Biology, University of Nottingham, University Park, Nottingham NG7 2RD, UK. Tel: +44(0) 1159513208 . Fax: + $44(0) 115$ 9513251. E-mail: jerzy.behnke@nottingham.ac.uk (e.g. rivers, lakes, mountain ranges, deserts) and communities of animals living in such isolated or semi-isolated patches of the environment can act as models for the consequences of human activities on habitat structure (Gilbert et al. 1998). Isolated or semi-isolated subpopulations of animals may experience different selection pressures created by the specific conditions in their home range. The degree to which subpopulations evolve in response to these selection differences will depend on the extent of gene flow, with consequences for the adaptations of the overall population. This is the geographical mosaic theory of co-evolution (Thompson, 1994). If animals living in isolated patches experience different ranges of infectious organisms, selection pressures in relation to infection may vary among sites; if gene flow is low, the resulting life-history strategies may differ profoundly as investment in defences 
against infection is traded off or takes priority over investment in other physiological/reproductive activities (Thompson, 1994; Sheldon \& Verhulst, 1996; Barnard et al. $2003 a, b$ ).

In our earlier publications, building on the comprehensive literature on the biology/ecology of bank voles and their helminth parasites (Flowerdew, Gurnell \& Gipps, 1985; Haukisalmi \& Henttonen, 2000; Bujalska \& Hansson, 2000), we showed that among the extensively managed forests of NE Poland, helminth communities differ between subpopulations of voles living in forest patches that are ecologically very similar, but isolated from each other by natural barriers (Behnke et al. 2001). These differences are reflected in variation in species richness, indices of diversity and occurrence of representative species from the regional helminth fauna. Moreover, voles from sites in which they were challenged more intensively by parasitic infections had significantly larger adrenal glands, testes and seminal vesicles for their age and body size, and showed greater asymmetry in hind feet (a possible measure of developmental instability, Barnard et al. 2002). Their corticosterone levels were higher and levels of aggression towards males from other sites lower, implying that fundamental differences in host physiology and behavioural ecology may arise from differences in parasite exposure experienced locally in their home ranges (Barnard et al. 2003a).

Rodent communities living in sandy deserts have also been studied intensively (Price, 1986; Brown, 1989; Kotler \& Brown, 1999), in contrast to those living in rocky deserts (Jones, Mandelik \& Dayan, 2001), although there is some literature on the latter, especially in the context of transmission of leishmaniasis in Russia (see Molyneux \& Ashford, 1983). Spiny mice in particular (Acomys spp.) have attracted attention as potential models for adaptation by small mammals to xeric environments (Jones \& Dayan, 2000), but in contrast to bank voles, relatively little is known still about the ecology of their helminth parasites. In a parallel study in the montane wadis in the south of the Sinai Peninsula in Egypt, we have shown that spiny mice (Acomys dimidiatus) from neighbouring but semi-isolated wadis also experienced differences in parasite exposure and that mice from wadis where parasite challenge was high were less inquisitive and aggressive compared with those from wadis where they experienced less helminth infection (Behnke et al. 2000; Barnard et al. 2003 b). These studies concentrated on wadis in close proximity to the village of St Katherine where our field station is located and on sites that could be accessed relatively easily by vehicles. In the present work we explored additional helminth communities in spiny mice from more distant wadis.

The objectives of this study were (1) to extend our documentation of helminth populations infecting local $A$. dimidiatus in the region and (2) to provide quantitative data on helminth communities in 4 neighbouring and varyingly separated sites, which are all part of the wadi network fragmenting the mountain massif that constitutes the southern tip of the Sinai peninsula, but differ from one another in subtle aspects of their ecology (Gilbert et al. 1996; Zalat et al. 2001). Since the current study identified one wadi in which mice were profoundly more subject to helminth infections than in others (3), the discovery provides an opportunity for a more focused analysis of the plasticity of life-history strategies in A. dimidiatus in relation to cost of infection. Moreover, our data provide a baseline for comparisons in the future (4) as host and parasite communities are monitored in the long-term, facilitating evaluation of the temporal stability of host and helminth communities in semi-isolated, xeric habitats. The results from such work will have implications for the role and importance of infection in fragmented host populations throughout the World, whether arising naturally or though human intervention.

\section{MATERIALS AND METHODS}

\section{Study sites}

Fieldwork was conducted over a 4-week period in August-September 2000 and was based at the Environmental Research Centre (ERC) of Suez Canal University, located on the periphery of the town of St Katherine, South Sinai, Egypt. Trapping was carried out in 4 sites in the vicinity of St Katherine (Fig. 1). The local environment has been described by Hobbs (1995) and Zalat \& Gilbert (1998). Two of the sites were identical to those sampled by Behnke et al. 2000 (Wadi El Arbaein and Wadi Gebal) but to our knowledge, rodents from the other 2 sites have not been examined previously. An important feature of all 4 wadis is the many walled Bedouin gardens, built around sources of water. These act as foci for the local fauna. Where possible trapping took place in or near these gardens, and these can be considered as discrete resource patches in the otherwise arid rocky and sandy landscape. When traps were deployed higher up the slopes of the wadis, other desert rodents dominated (Dipodyllus and Gerbillus spp.) rather than Acomys spp.

Wadi El Arbaein (Site 1 and called Wadi El Lega until 1979) leads away south-eastwards from the town of St Katherine and has been described comprehensively (Willmer et al. 1994; Gilbert et al. 1996). The ERC is based at the north-western end, essentially at the mouth of this wadi on the edge of the village of St Katherine (Global Positioning Satellite reference [GPS in decimal degrees] N28.553440-E33.947963, altitude $1630 \mathrm{~m}$ ), where we began trapping. Our most distant trapping site in this wadi was located approximately $2.7 \mathrm{~km}$ southeast of ERC (GPS N28.534327-E33.965172, altitude 


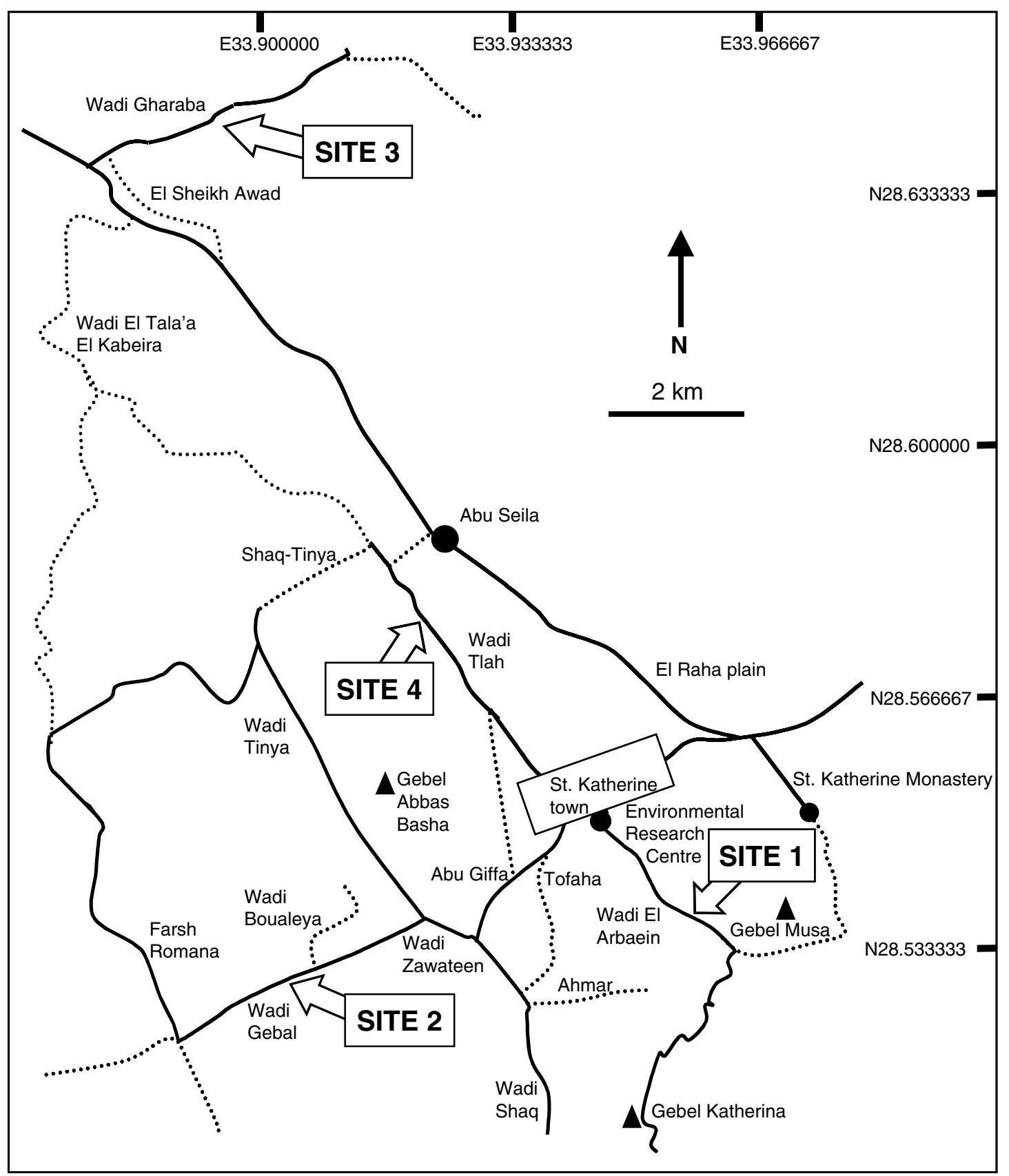

Fig. 1. Map of the region surrounding our 4 study sites. At the centre of the region is the village of St Katherine. The scale bar $=2 \mathrm{~km}$. GPS references are given in the text and along the vertical and horizontal axes. The bold arrows point to approximately the centre of each study site.

$1730 \mathrm{~m})$. This site had been sampled previously and was therefore a useful baseline reference (Behnke et al. 2000; Barnard et al. 2003 b).

Wadi Gebal runs westward from St Katherine (Site 2, GPS N28.53342-E33.908398, altitude $1888 \mathrm{~m})$. It is part of a system of wadis separated from St Katherine by a ridge of mountains and is the highest and most isolated of the 4 sites (Zalat \& Gilbert, 1998). Access to Wadi Gebal from St Katherine requires negotiation of the high mountain passes at Abu Giffa, and above Wadi Zawateen, the latter leading across a high mountain plateau into Wadi Gebal itself. The furthest trapping site in this wadi was $5.8 \mathrm{~km}$ from the ERC (N28.526686-E33.896420, altitude $1892 \mathrm{~m}$ ).

Wadi Gharaba (Site 3), the most distant of the 4 sites from the ERC, is located approximately $11.9 \mathrm{~km}$ north of St Katherine (GPS N28.64672-E33.88991, altitude $1130 \mathrm{~m}$ to N28.65179-E33.90107, altitude $1154 \mathrm{~m}$ ) and has the lowest altitude of the 4 sites. There is continuity along the wadi floor with Wadi Tlah, but passage is not easy, requiring negotiation of several rock falls, and steep ascents along the tortuous route to Wadi Tlah and eventually St Katherine.

Wadi Tlah (also known as Wadi I'Tlah and Telah, Site 4) is a long deep wadi that is linked to the plain 
of St Katherine by a narrow gorge and low pass (E1 Milqaa; GPS N28.56452-E33.93682, altitude $1675 \mathrm{~m}$, distance from ERC SCU $1.6 \mathrm{~km}$ ), and descends in a north-westerly direction to Wadi El Talaa El Kabeira. We trapped rodents along the length of this wadi, starting at the top end near to St Katherine, and to a distance of $4.9 \mathrm{~km}$ (N28.58950-E33.91936, altitude $1366 \mathrm{~m}$ ) from ERC SCU.

\section{Collection of rodents}

At each site, rodents were caught live in Sherman traps, placed selectively among the rocks and boulders, mostly in the wadi bases, around walled gardens, and occasionally along the lower slopes. These were set out at dusk, and inspected in the early morning before exposure to direct sunlight. All traps were brought into the local camp where the animals were removed, identified and processed. Traps were re-set the following evening. All trapped animals were sexed, weighed, measured and scrutinized for any obvious lesions, blood samples were taken and faecal material collected from traps for analysis, then they were either fur-marked individually and released near to the point of capture, or brought back to the ERC at St Katherine for autopsy. A maximum of $40 \%$ of the captured mice from each site were culled (by agreement with the St Katherine Protectorate authorities). For logistic reasons, it was not possible to sample all wadis simultaneously throughout the 4-week period. The sequence of sampling was Wadi El Arbaein, Wadi Gebal, Wadi Gharaba and finally Wadi Tlah. Total trapping effort was 8896 trap hours (a trap hour being 1 trap deployed in the field for $1 \mathrm{~h}$ ) and the average number of animals caught per 100 trap hours was 1.9. This was divided among wadis as follows: Wadi El Arbaein, 2723 trap hours (30.6\% of total, $2 \cdot 31$ mice per 100 trap hours), Wadi Gebal, $1838(20 \cdot 7 \%, 1 \cdot 74)$, Wadi Gharaba, $2136(24 \%, 1 \cdot 31)$ and Wadi Tlah, $2199(24 \cdot 7 \%, 2 \cdot 09)$.

\section{Faecal egg counts}

Faecal samples were recovered from traps after the animals had been removed (hence overnight samples) and were preserved in SAF $(0.9 \% \mathrm{w} / \mathrm{v}$ sodium acetate, $2 \%$ acetic acid, $4 \%$ formaldehyde, $\mathrm{pH} 4 \cdot 15$ ) fluid in $1.5 \mathrm{ml}$ sample tubes. In some cases, where no faeces were deposited in traps, animals were kept at the ERC in cages with wire bases, and additional overnight faecal material was collected. In Nottingham, all samples were centrifuged at $1000 \mathrm{rpm}$ for $10 \mathrm{~min}$, and the volume of the deposit was recorded. The deposit was then re-suspended in a known volume of water and ten $10 \mu \mathrm{l}$ samples examined on a microscope slide, and all the eggs of each type counted. Total egg counts were converted into eggs per $\mathrm{ml}$ (EPM) of faecal deposit (mean no. of eggs $/ 10 \mu 1$ sample $\times 100 \times$ total volume of suspension $(\mathrm{ml})$, divided by total volume $(\mathrm{ml})$ of the original faecal deposit). Eggs were identified after inspection of female worms from the autopsied animals. Eggs from the 4 species of spirurids could not be distinguished from one another, nor was it possible to distinguish between tapeworm eggs. However, those of D. kuntzi, A. tetraptera and S. minuta are all very distinct. As part of quality control, and in order to confirm the relevance of faecal egg counts (FEC), we examined the relationship between EPM and total spirurid worm burden in autopsied mice $\left(r_{s}=0.71\right.$, $n=66, P<0 \cdot 001)$ and spirurid biomass $\left(r_{s}=0 \cdot 82\right.$, $n=63, P<0 \cdot 001)$ and both were positive and highly significant. Confining the analysis to mice that had at least 1 worm and positive FEC, in order to avoid the skewing effect of multiple double zero values, gave $r_{s}=0.50 \quad(n=23, P=0.014)$ and $r_{s}=0.78 \quad(n=23$, $P<0 \cdot 001)$ respectively.

\section{Sampling of hosts}

At the ERC, animals selected for autopsy were culled ( $40 \%$ of the catch), weighed (to the nearest $0 \cdot 1 \mathrm{~g}$ ), sexed and relevant morphometric data were recorded (see below). The entire alimentary tract was removed, placed in plastic universals containing 10\% formalin and the livers, lungs and body cavity were inspected for helminths. Those recovered from organs and body cavities were preserved in $70 \%$ ethanol. Preserved intestines and parasites were imported into the UK under a licence from the Department of Environmental, Food and Rural Affairs (UK), for detailed examination and were all processed by July 2001.

Two age classes were established for the smaller data set based on autopsied animals $(n=67)$. We entered values obtained in the laboratory from freshly killed animals for mouse body weight, length from the tip of the nose to the anus, the length of the femur, head length, head width and dry weight of both eye lenses combined (Morris, 1972) into a Principal Components Analysis (PCA). This generated just one significant component (here called SIZE), accounting for $90 \cdot 1 \%$ of the variation in the data (weighting of all component variables was positive, ranging from 0.925 for skull width to 0.967 for body weight), which was used as the primary determinant of age class. The border between these categories was established by other indicators of maturity. Young spiny mice have soft juvenile hair that is gradually and systematically replaced from the posterior towards the anterior of the body by spiny hair, leaving an apparent age-dependent moult line. Maturity in males was also indicated by scrotal testes and in females by perforate vaginas. All pregnant and lactating females were classified in the adult age class. After allocation to age classes, SIZE ranged from -1.9 to -0.3 in juvenile mice, and from 0.19 to 

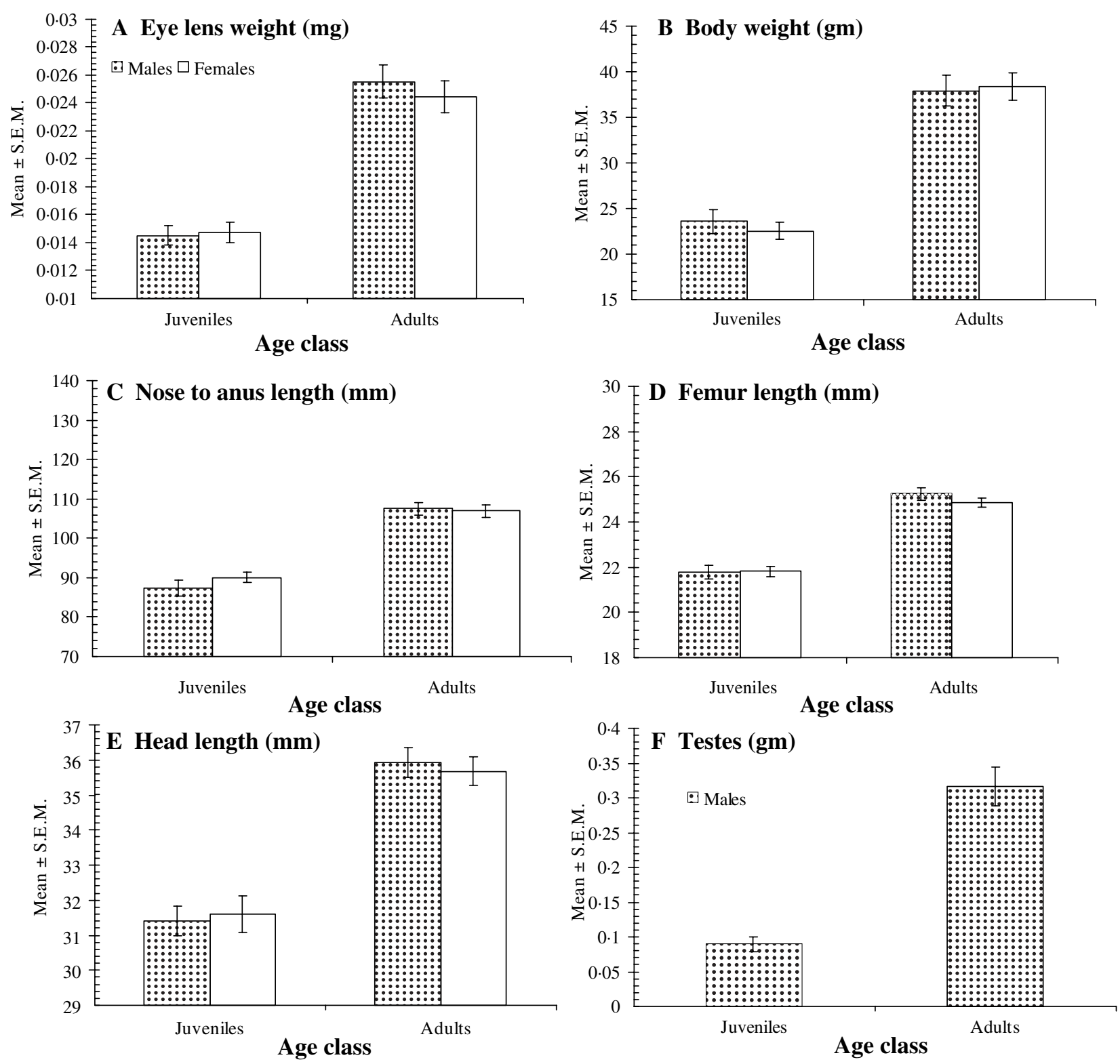

Fig. 2. Relationship between the two assigned age classes and 5 of the morphometric measures employed in calculating Principal Component 1, on the basis of which mice were separated into age class 1 (juveniles) and age class 2 (adults). The relationship with head width is not shown, but mean testes weight among male mice is illustrated to emphasize the maturity of animals in age class 2 compared with age class 1 . Only the main effect of age was significant in each case. (A) Dry lens weight $\left(F_{1,64}=80 \cdot 8, P<0 \cdot 0001\right)$; (B) host body weight $\left(F_{1,64}=91 \cdot 3, P<0 \cdot 0001\right)$; (C) nose to anal length $\left(F_{1,64}=110 \cdot 9\right.$, $P<0 \cdot 0001)$; (D) femur length $\left(F_{1,64}=154 \cdot 9, P<0 \cdot 0001\right)$; (E) head length $\left(F_{1,64}=84 \cdot 0, P<0 \cdot 0001\right)$; (F) testes weight $\left(F_{1,30}=45 \cdot 8, P<0 \cdot 0001\right)$.

+1.77 in adults. To confirm that age class 1 and age class 2 were broadly reflected in growth and maturation of mice, we carried out 2-way analyses of variance with each morphometric measurement in turn as the dependent variable, and the two age classes and sex as the factors. Neither sex nor the interaction between sex and age were significant but in all cases the effect of age was highly significant (Fig. 2). Age class 1 contained all the weanlings, and juvenile mice. Age class 2 included only adult mice.

In order to enable analysis of FEC, which were available for the larger data set, we allocated mice to
3 age classes based on parameters measured in the field on live animals. These were less accurate than values obtained in the laboratory because they were taken from animals that were fully conscious but restrained by being held firmly. We excluded from the analysis animals that were only measured in the laboratory $(n=8)$ and those with incomplete morphometric data sets. Among this larger data set, comprising 168 mice in total, complete measurements of body weight, nose-to-anus length, anus-totail tip length, mean hind foot length and skull width were available for 144 mice. These were entered into 
PCA and only one principal component (SIZE) was derived, accounting for $61 \cdot 1 \%$ of the variance (weighting of all component variables was positive, ranging from 0.646 for hind foot length to 0.894 for body weight). Additional evidence, based on sexual and morphological development of mice, and for autopsied animals, previous allocation to age class 1 and age class 2 , was then used to place mice into appropriate age classes. These factors were also employed to allocate the 24 mice for which SIZE was not available to age classes (after adjustment, the limits of SIZE for the 3 age classes were: age class $1=-2 \cdot 65$ to $-0 \cdot 27$, age class $2=-1 \cdot 07$ to $+0 \cdot 63$, and age class $3=-0 \cdot 19$ to $+3 \cdot 11)$. Once established, ANOVA of each of the parameters used, with age class and sex as factors, gave highly significant main effects of age in all cases, each parameter increasing with age class. However, in the case of foot length, nose-anus length and skull width there were also significant effects of sex, with female mice showing marginally lower values in all cases (data not illustrated but available from JMB on request). In this case age class 1 comprised weanlings and very young juveniles, age class 2 juveniles and young adults, and age class 3 adult mice.

\section{Identification of worms}

Helminths were identified by conventional microscopy, aided by scanning electron microscopy, where relevant, as described previously (Behnke et al. 2000) and by reference to earlier literature (e.g. Greenberg, 1969). The scanning electron microscope was particularly important in distinguishing between spirurid worms, which are best identified through comparison of the morphology of their mouthparts (Chabaud, 1975).

\section{Measures of community structure}

Following reports by Kennedy \& Hartvigsen (2000) and Behnke et al. (2001), measures of component community structure were the total number of helminth species, the Berger-Parker dominance index and Simpson's index of diversity (unbiased as $\left(1-\Sigma p_{\mathrm{i}}^{2}\right) \times(n / n-1)$ where $n=$ total number of helminths in the sample; Washington, 1984) for each site in turn. The degree of similarity between component communities was assessed by Jaccard's index of similarity comparing in turn each of the 6 possible combinations of pairs of sites. Infracommunity structure was assessed by mean number of helminth species per mouse, maximum number of helminth species and species density distribution across the sample, mean number of helminth and nematode individuals per mouse, mean Brillouin's index per mouse (infected and uninfected), maximum Brillouin's index, mean abundance and prevalence of individual species.

\section{Statistical analysis}

The data employed in analysis were based on autopsied mice (the smaller data set) and separately on faecal egg counts (the larger sample). The latter included faeces from the autopsied mice, but not recaptured mice and therefore the analysis is not confounded by repeated measures.

The frequency distribution of infracommunity species richness was tested for goodness of fit to the positive binomial distribution (assumption of the null model is a regular distribution), the Poisson distribution (assumption of the null model is a random distribution), the negative binomial model (assumption of the null model is an aggregated distribution) and the null model of Janovy et al. (1995) (assumption of the null model is that, in the absence of associations and interactions between species, the frequency distribution of infracommunity species richness is predicted by prevalence values of all the species comprising the component community). All distributions were tested for goodness of fit by $\chi^{2}$.

Prevalence data (percentage of animals infected) are shown with $95 \%$ confidence limits, calculated as described by Rohlf \& Sokal (1995) and are based on worms recovered at autopsy or faecal egg counts, as stated. In both cases, prevalence was analysed by maximum likelihood techniques based on log linear analysis of contingency tables using the software package Statgraphics Version 7. Full factorial models incorporated age (2 or 3 age classes), site (4 levels), sex (2 levels, males and females) and infection as a binary factor (present/absent). Beginning with the most complex model, involving all possible main effects and interactions, those combinations which did not contribute significantly to explaining variation in the data were eliminated in a stepwise fashion, beginning with the highest level interaction. A minimum sufficient model was then obtained, for which the likelihood ratio of $\chi^{2}$ was not significant, indicating that the model was sufficient in explaining the data. The importance of each term (i.e. interactions involving infection) in the final model is assessed by the probability that its exclusion will alter the model significantly.

Summary figures for parasite abundance are expressed as arithmetic means \pm s.E.M. These means reflect the abundance of infection as defined by Margolis et al. (1982) and Bush et al. (1997) and include all subjects within the specified group, infected and not infected, for which relevant data were available. Because of the discontinuous distribution of faecal egg counts, all the values in each subset were divided by the value of the lowest count prior to analysis (for spirurids and total helminths $=173$, for total nematodes $=108$ ) and the data are given as $\log _{10}(\mathrm{EPM} / 173+1)$ and $\log _{10}(\mathrm{EPM} / 108+1)$, respectively. Back-transformed, geometric means are referred to in the text. 
Table 1. Numbers of Acomys dimidiatus examined and autopsied by site, and host sex and age

(Statistical analysis: The minimum sufficient models for: (1) all the examined animals $=\operatorname{sex} \times$ age class $+\operatorname{site}\left(\chi^{2}=12 \cdot 4\right.$, D.F. $=15, P=0 \cdot 65)$, (2) the autopsied animals $=$ no interactions or main effects $\left(\chi^{2}=9 \cdot 8\right.$, D.F. $\left.=15, P=0 \cdot 8\right)$. The significance of omitting each term respectively is given in the text.)

\begin{tabular}{|c|c|c|c|c|c|c|c|c|c|c|}
\hline \multirow[b]{3}{*}{ Site } & \multirow[b]{3}{*}{ Sex } & \multicolumn{7}{|c|}{ Age class } & \multirow{3}{*}{$\begin{array}{l}\text { Total } \\
\text { by sex }\end{array}$} & \multirow{3}{*}{$\begin{array}{l}\text { Total } \\
\text { by sit }\end{array}$} \\
\hline & & \multicolumn{2}{|c|}{ Autopsied mice } & \multirow{2}{*}{$\begin{array}{l}\text { Total } \\
\text { by sex }\end{array}$} & \multirow{2}{*}{$\begin{array}{l}\text { Total } \\
\text { by site }\end{array}$} & \multicolumn{3}{|l|}{ All mice } & & \\
\hline & & Class 1 & Class 2 & & & Class 1 & Class 2 & Class 3 & & \\
\hline \multirow[t]{3}{*}{ Arbaein } & Male & 5 & 5 & 10 & & 7 & 16 & 7 & 30 & \\
\hline & Female & 4 & 7 & 11 & & 11 & 8 & 13 & 32 & \\
\hline & Combined & 9 & 12 & & 21 & 18 & 24 & 20 & & 62 \\
\hline \multirow[t]{3}{*}{ Gebal } & Male & 3 & 4 & 7 & & 3 & 9 & 2 & 14 & \\
\hline & Female & 2 & 5 & 7 & & 4 & 6 & 8 & 18 & \\
\hline & Combined & 5 & 9 & & 14 & 7 & 15 & 10 & & 32 \\
\hline \multirow{3}{*}{ Gharaba } & Male & 2 & 4 & 6 & & 1 & 5 & 5 & 11 & \\
\hline & Female & 2 & 5 & 7 & & 2 & $6^{*}$ & 9 & 17 & \\
\hline & Combined & 4 & 9 & & 13 & 3 & 11 & 14 & & 28 \\
\hline \multirow[t]{3}{*}{ Tlah } & Male & 3 & 6 & 9 & & 4 & 9 & 11 & 24 & \\
\hline & Female & 3 & 7 & 10 & & 4 & 5 & 13 & 22 & \\
\hline & Combined & 6 & 13 & & 19 & 8 & 14 & 24 & & 46 \\
\hline \multicolumn{11}{|l|}{ Total by sex } \\
\hline & Males & 13 & 19 & 32 & & 15 & 39 & 25 & 79 & \\
\hline & Females & 11 & 24 & 35 & & 21 & 25 & 43 & 89 & \\
\hline Total by age & & 24 & 43 & & & 36 & 64 & 68 & & \\
\hline Grand total & & & & & 67 & & & & & 168 \\
\hline
\end{tabular}

* Neither field morphometric measurements nor faecal samples were available from one age class 2 female from Wadi Gharaba.

The degree of aggregation in the worm counts was calculated by the index of discrepancy $(D)$, as described by Poulin (1993) (a value of 0 indicates an even distribution of counts across all hosts and a value of 1 indicates all parasites aggregated in a single host), and the index of dispersion ( $I$, variance to mean ratio, where values $>1$ indicate over-dispersed data). Frequency distributions of individual species were also tested for goodness of fit to negative binomial, positive binomial and Poisson models by $\chi^{2}$, as described by Elliott (1977), and the negative binomial exponent $k$ is given as appropriate.

Parasite abundance was analysed by GLIM (Generalised Linear Interactive Modelling; GLIM 4, PC version, Royal Statistical Society 1993), as described previously (Abu-Madi et al. 1998). Where data conformed to negative binomial distributions, we first evaluated models with negative binomial error structures, as models of choice, but these did not converge satisfactorily. Hence, models with normal errors were fitted after normalization of the data by $\log _{10}(x+1)$ transformation (Crawley, 1993; Wilson \& Grenfell, 1997; Behnke et al. 1999). Site (4 levels), host age (2 levels for worm counts but 3 for faecal egg counts) and host sex (2 levels) were entered as factors. We began in all cases with full factorial models, including all main effects and interactions, and then progressively simplified them by deletion of terms, beginning with the highest order interactions, and progressing to the main effects. Two-way interactions were first deleted to register the change in deviance and then reinstated in turn until all 3 had been evaluated. All 2-way interactions were then removed, and the procedure was repeated with the main effects. Finally, minimum sufficient models were fitted, entering only the significant terms, to obtain probabilities and the residuals from these were checked for approximately normal distribution.

If the data did not satisfy the required assumptions, we employed non-parametric 1-way ANOVA (Kruskal-Wallis test) for multiple level factors (effect of site) and the Mann-Whitney $U$ test for two samples (effects of host sex and age on worm counts). Correlations between continuous variables were analysed by the non-parametric Spearman's Correlation Coefficient test.

RESULTS

Acomys dimidiatus

A total of 168 spiny mice were sampled from the 4 study sites, of which 67 were autopsied and 167 provided faecal samples. The structure of the host population by site, host sex and age is summarized in Table 1. For the larger data set there was a significant difference in the numbers of animals sampled by wadi $\left(\chi^{2}=17 \cdot 4\right.$, D.F. $=3, P=0 \cdot 0006 ; 36 \cdot 9 \%$ of the 
Table 2. Percentage distribution of higher taxa by site

\begin{tabular}{llccc}
\hline \hline & \multicolumn{3}{l}{ Percentage distribution by site } \\
\cline { 2 - 5 } & Arbaein & Gebal & Gharaba & Tlah \\
\hline All helminths as a \% of grand total* & $19 \cdot 3$ & $9 \cdot 5$ & $37 \cdot 7$ & $33 \cdot 4$ \\
All helminths adjusted for & $14 \cdot 7$ & $10 \cdot 9$ & $46 \cdot 4$ & $28 \cdot 1$ \\
$\quad$ sampling effort** & & & & \\
Intestinal nematodes** & $13 \cdot 2$ & $11 \cdot 6$ & $48 \cdot 6$ & $26 \cdot 7$ \\
Strobilate intestinal cestodes** & $33 \cdot 1$ & $59 \cdot 6$ & 0 & $7 \cdot 3$ \\
Larval cestodes** & $19 \cdot 8$ & 0 & 0 & $80 \cdot 2$ \\
Acanthocephala** & $62 \cdot 0$ & 0 & $38 \cdot 0$ & 0 \\
\hline \hline
\end{tabular}

* Values based on total number of helminths recovered from each site without adjustment for sample size.

** The percentage distribution is based on data adjusted for sample size in all cases except the top line.

mice were from Wadi Arbaein, 27.4\% from Wadi Tlah, $19 \cdot 0 \%$ from Wadi Gebal and $16 \cdot 7 \%$ from Wadi Gharaba). There was also a significant interaction between sex and age class ('Table $1, \chi^{2}=8 \cdot 9$, D.F. $=2$, $P=0 \cdot 011)$, reflecting variation in the balance of sexes among mice of different ages. For the smaller data set based on autopsied animals no significant differences were found.

\section{Regional helminth community structure}

The regional helminth community, as reflected by the combined data from all four sites, was clearly dominated by intestinal nematodes. Of the 1375 helminths recovered, $88.7 \%$ were intestinal nematodes, $6 \cdot 1 \%$ larval cestodes, $2 \cdot 9 \%$ acanthocephalans, $1.5 \%$ tissue nematodes and $0.9 \%$ strobilate intestinal cestodes. Interestingly, arthropod-transmitted nematodes represented $51 \cdot 6 \%$ of all helminths recovered, and $58 \cdot 2 \%$ of the intestinal nematodes. The remainder were monoxenous species.

\section{Measures of component community structure}

Higher taxa. Table 2 shows that over $70 \%$ of the helminths were from just 2 wadis, Gharaba and Tlah, and after correction for variation in sampling effort, it can be seen that $48.6 \%$ of the intestinal nematodes were from Wadi Gharaba, almost twice as many as from Wadi Tlah and 3-4 times as many as from Wadis Arbaein and Gebal, respectively. In contrast, most of the strobilate intestinal cestodes were recovered from Wadi Gebal, most larval cestodes from Wadi Tlah and most acanthocephalans from Wadi Arbaein. Arthropod-transmitted nematodes were dominant in Wadis Gharaba ( $82 \cdot 3 \%$ of all helminths) and El Arbaein (62.4\%), and less important in Wadis Tlah (20.7\%) and Gebal (16\%).

Total species richness and component species. Fourteen species of helminths were recorded in total,
8 nematodes, 5 cestodes and 1 acanthocephalan (Table 3). The nematodes included 20 larval stages of an unidentified species that were found encysted in the mesenteries and peritoneal walls of one mouse from Wadi Gharaba (see Greenberg, 1969). Sixtythree mice $(94.0 \%)$ carried at least one species. P. muricola $(47 \cdot 8 \%)$ and D. kuntzi $(46 \cdot 3 \%)$ were the most prevalent helminths among all the mice combined, but there were marked differences in their prevalence, as well as that of other helminths, between sites.

Total species richness, dominant species, diversity and similarity indices by site. The numbers of helminth species recorded in the mice from Wadis Arbaein and Tlah were higher than those from mice in Wadis Gebal and Gharaba (Table 4), but these latter sites were also those with the smaller sample sizes. However, mice from Wadi Gharaba clearly showed the highest Berger-Parker dominance index and the lowest Simpson's diversity index because of the relatively high worm burdens with $P$. muricola in the mice from this site. Of the $662 P$. muricola recovered, $64 \cdot 4 \%$ were from the 13 mice from Wadi Gharaba. At the component community level, P. muricola was also the dominant species in Wadi Arbaein, whilst S. minuta was the dominant species in both Wadi Gebal and Wadi Tlah.

In terms of similarity, the helminth component community from Wadi Arbaein was closest to Wadi Gharaba and Tlah, sharing respectively 6 and 7 species.

\section{Measures of infracommunity structure}

Mean species richness. The overall mean number of helminth species harboured per host (all mice combined, $n=67$ ) was $1 \cdot 85 \pm 0 \cdot 128$ (variance to mean ratio $=0 \cdot 59)$. Mean species richness was highest in Wadi Tlah and lowest in Wadi Gebal (Table 5) and this difference between the wadis was significant 
Table 3. Prevalence (\% infected) of helminth taxa by site based on autopsied mice $(n=67)$ and on faecal egg counts $(n=167)$

\begin{tabular}{|c|c|c|c|c|c|}
\hline \multirow[b]{2}{*}{ Taxon } & \multirow[b]{2}{*}{ Species } & \multicolumn{4}{|l|}{ Site } \\
\hline & & Arbaein* & Gebal* & Gharaba* & Tlah* \\
\hline \multirow[t]{4}{*}{ Nematodes } & Protospirura muricola & $42 \cdot 9 \pm 21 \cdot 2$ & 0 & $92 \cdot 3 \pm 14 \cdot 5$ & $57 \cdot 9 \pm 22 \cdot 2$ \\
\hline & Mastophorus muris & $14 \cdot 3 \pm 15 \cdot 0$ & $28 \cdot 6 \pm 23 \cdot 7$ & $7 \cdot 7 \pm 14 \cdot 5$ & $26 \cdot 3 \pm 19 \cdot 8$ \\
\hline & Streptopharagus kuntzi & $4 \cdot 8 \pm 9 \cdot 1$ & 0 & 0 & $15 \cdot 8 \pm 16 \cdot 4$ \\
\hline & Streptopharagus numidicus & 0 & $14 \cdot 3 \pm 18 \cdot 3$ & 0 & 0 \\
\hline \multicolumn{2}{|c|}{ All spirurids (worm counts) } & $57 \cdot 1 \pm 21 \cdot 2$ & $35 \cdot 7 \pm 25 \cdot 1$ & $92 \cdot 3 \pm 14 \cdot 5$ & $73 \cdot 7 \pm 19 \cdot 8$ \\
\hline & $14 \cdot 5 \pm 8 \cdot 8$ & $21 \cdot 9 \pm 14 \cdot 3$ & $70 \cdot 4 \pm 17 \cdot 2$ & $30 \cdot 4 \pm 13 \cdot 3$ \\
\hline \multicolumn{2}{|c|}{$\begin{array}{l}\text { All spirurids (FEC)*** } \\
\text { Dentostomella kuntzi (worm counts) }\end{array}$} & $42 \cdot 9 \pm 21 \cdot 2$ & $28 \cdot 6 \pm 23 \cdot 7$ & $46 \cdot 2 \pm 27 \cdot 1$ & $63 \cdot 2 \pm 21 \cdot 7$ \\
\hline \multicolumn{2}{|r|}{ Dentostomella kuntzi(FEC)** } & $3 \cdot 2 \pm 4 \cdot 4$ & $12 \cdot 5 \pm 11 \cdot 5$ & 0 & $2 \cdot 2 \pm 4 \cdot 2$ \\
\hline \multicolumn{2}{|r|}{ Syphacia minuta } & $14 \cdot 3 \pm 15 \cdot 0$ & $42 \cdot 9 \pm 25 \cdot 9$ & $15 \cdot 4 \pm 19 \cdot 6$ & $31 \cdot 6 \pm 20 \cdot 9$ \\
\hline \multicolumn{2}{|r|}{ Aspiculuris africana } & $14 \cdot 3 \pm 15 \cdot 0$ & $7 \cdot 1 \pm 13 \cdot 5$ & $7 \cdot 7 \pm 14 \cdot 5$ & $36 \cdot 8 \pm 21 \cdot 7$ \\
\hline \multicolumn{2}{|c|}{ All nematodes (worm counts) } & $85 \cdot 7 \pm 15 \cdot 0$ & $78 \cdot 6 \pm 21 \cdot 5$ & 100 & 100 \\
\hline \multicolumn{2}{|c|}{ All nematodes (FEC) $)^{* *}$} & $21 \cdot 0 \pm 10 \cdot 1$ & $34 \cdot 4 \pm 16 \cdot 5$ & $70 \cdot 4 \pm 17 \cdot 2$ & $34 \cdot 8 \pm 13 \cdot 8$ \\
\hline \multirow[t]{3}{*}{ Cestodes } & Rodentolepis negevi & 0 & $14 \cdot 3 \pm 18 \cdot 3$ & 0 & $5 \cdot 3 \pm 10 \cdot 0$ \\
\hline & Rodentolepis nana & $4 \cdot 8 \pm 9 \cdot 1$ & 0 & 0 & 0 \\
\hline & Witenbergitaenia $\mathrm{sp}$. & 0 & $7 \cdot 1 \pm 13 \cdot 5$ & 0 & 0 \\
\hline \multicolumn{2}{|c|}{ All adult cestodes (worm counts) } & $14 \cdot 3 \pm 15 \cdot 0$ & $14 \cdot 3 \pm 18 \cdot 3$ & 0 & $5 \cdot 3 \pm 10 \cdot 0$ \\
\hline \multicolumn{2}{|c|}{ All adult cestodes $(\mathrm{FEC}) * *$} & $9 \cdot 7 \pm 7 \cdot 4$ & $9 \cdot 4 \pm 10 \cdot 1$ & $3 \cdot 7 \pm 7 \cdot 1$ & $2 \cdot 2 \pm 4 \cdot 2$ \\
\hline \multirow{2}{*}{\multicolumn{2}{|c|}{$\begin{array}{l}\text { Mesocestoides } \mathrm{sp} . \\
\text { Foyeuxiella rosssicum }\end{array}$}} & $9 \cdot 5 \pm 12 \cdot 6$ & 0 & 0 & $5 \cdot 3 \pm 10 \cdot 0$ \\
\hline & & 0 & 0 & 0 & $5 \cdot 3 \pm 10 \cdot 0$ \\
\hline \multicolumn{2}{|c|}{ All larval cestodes } & $9 \cdot 5 \pm 12 \cdot 6$ & 0 & 0 & $10 \cdot 5 \pm 13 \cdot 8$ \\
\hline \multicolumn{2}{|c|}{ All cestodes } & $19 \cdot 0 \pm 16 \cdot 8$ & $14 \cdot 3 \pm 18 \cdot 3$ & 0 & $15 \cdot 8 \pm 16 \cdot 4$ \\
\hline \multicolumn{6}{|c|}{ Acanthocephala } \\
\hline \multirow{2}{*}{\multicolumn{2}{|c|}{$\begin{array}{l}\text { Moniliformis acomysi } \\
\text { All helminths (worm counts) }\end{array}$}} & $4 \cdot 8 \pm 9 \cdot 1$ & 0 & $15 \cdot 4 \pm 19 \cdot 6$ & 0 \\
\hline & & $90 \cdot 5 \pm 12 \cdot 6$ & $85 \cdot 7 \pm 18 \cdot 3$ & 100 & 100 \\
\hline \multicolumn{2}{|c|}{ All helminths (FEC)** } & $27 \cdot 4 \pm 11 \cdot 1$ & $34 \cdot 4 \pm 16 \cdot 5$ & $74 \cdot 1 \pm 16 \cdot 5$ & $37 \cdot 0 \pm 13 \cdot 9$ \\
\hline
\end{tabular}

* Prevalence (\% infected) $\pm 95 \%$ confidence limits.

** Prevalence based on faecal egg counts.

Table 4. Measures of component community structure by site

\begin{tabular}{|c|c|c|c|c|}
\hline & \multicolumn{4}{|l|}{ Site } \\
\hline & Arbaein & Gebal & Gharaba & Tlah \\
\hline $\begin{array}{l}\text { Total no. of helminth } \\
\text { species identified }\end{array}$ & 9 & 7 & 7 & 9 \\
\hline $\begin{array}{l}\text { Berger-Parker dominance } \\
\text { index }\end{array}$ & $0 \cdot 598$ & $0 \cdot 588$ & $0 \cdot 821$ & $0 \cdot 484$ \\
\hline Dominant species & P. muricola & S. minuta & P. muricola & S. minuta \\
\hline Simpson's index of diversity & $0 \cdot 613$ & 0.597 & $0 \cdot 318$ & $0 \cdot 705$ \\
\hline \multicolumn{5}{|l|}{$\begin{array}{l}\text { Jacard's index of similarity } \\
\text { (Shared species) }\end{array}$} \\
\hline - Arbaein & & $0 \cdot 33(4)$ & $0 \cdot 60(6)$ & $0 \cdot 64(7)$ \\
\hline - Gebal & & & $0 \cdot 40(4)$ & $0 \cdot 45(5)$ \\
\hline - Gharaba & & & & $0 \cdot 45(5)$ \\
\hline
\end{tabular}

(3-way ANOVA with normal errors and site, host age and sex as factors, main effect of site $F_{3,65}=3 \cdot 04$, $0.05>P>0.025)$. There was also a significant main effect of host age $\left(F_{1,63}=4 \cdot 82,0.05>P>0.025\right)$, with adult mice showing a higher mean species richness $(2 \cdot 07 \pm 0 \cdot 17)$ compared to juveniles $(1 \cdot 46 \pm 0 \cdot 17)$. Although the extent of the difference between adult and juvenile mice varied between wadis, being most marked in mice from Wadi Gebal and least marked in mice from Wadi Arbaein (Fig. 3A), the interaction was not significant. With age and site taken into account, mean helminth species richness did not differ significantly between the sexes $($ males $=1 \cdot 69 \pm 0 \cdot 17$, females $=2 \cdot 00 \pm 0 \cdot 19$ ).

Measures of infracommunity diversity. The maximum number of helminth species per mouse ranged from 3 in Wadi Gharaba to 5 in Wadi Arbaein (Table 5). There was a significant difference in the value of Brillouin's diversity index across the four 
Table 5. Measures of infracommunity structure by site

\begin{tabular}{llllc}
\hline \hline & \multicolumn{2}{l}{ Site } & & \\
\cline { 2 - 5 } & Arbaein & Gebal & Gharaba & Tlah \\
\hline Mean number of species \pm s.E.M. & $1 \cdot 57 \pm 0 \cdot 25$ & $1 \cdot 43 \pm 0 \cdot 31$ & $1 \cdot 92 \pm 0 \cdot 21$ & $2 \cdot 42 \pm 0 \cdot 19$ \\
Maximum number of species & 5 & 4 & 3 & 4 \\
Mean no. of helminths \pm s.E.M. & $12 \cdot 7 \pm 7 \cdot 2$ & $9 \cdot 4 \pm 3 \cdot 8$ & $39 \cdot 9 \pm 9 \cdot 6$ & $24 \cdot 2 \pm 6 \cdot 2$ \\
Mean no. of nematodes \pm s.E.M. & $10 \cdot 2 \pm 6 \cdot 6$ & $8 \cdot 9 \pm 3 \cdot 8$ & $39 \cdot 1 \pm 9 \cdot 0$ & $20 \cdot 6 \pm 5 \cdot 9$ \\
Mean Brillouin's index \pm s.E.M. & $0 \cdot 203 \pm 0 \cdot 057$ & $0 \cdot 173 \pm 0 \cdot 082$ & $0 \cdot 304 \pm 0 \cdot 070$ & $0 \cdot 415 \pm 0 \cdot 053$ \\
Maximum Brillouin's index & $0 \cdot 750$ & $0 \cdot 888$ & $0 \cdot 632$ & $0 \cdot 813$ \\
\hline \hline
\end{tabular}
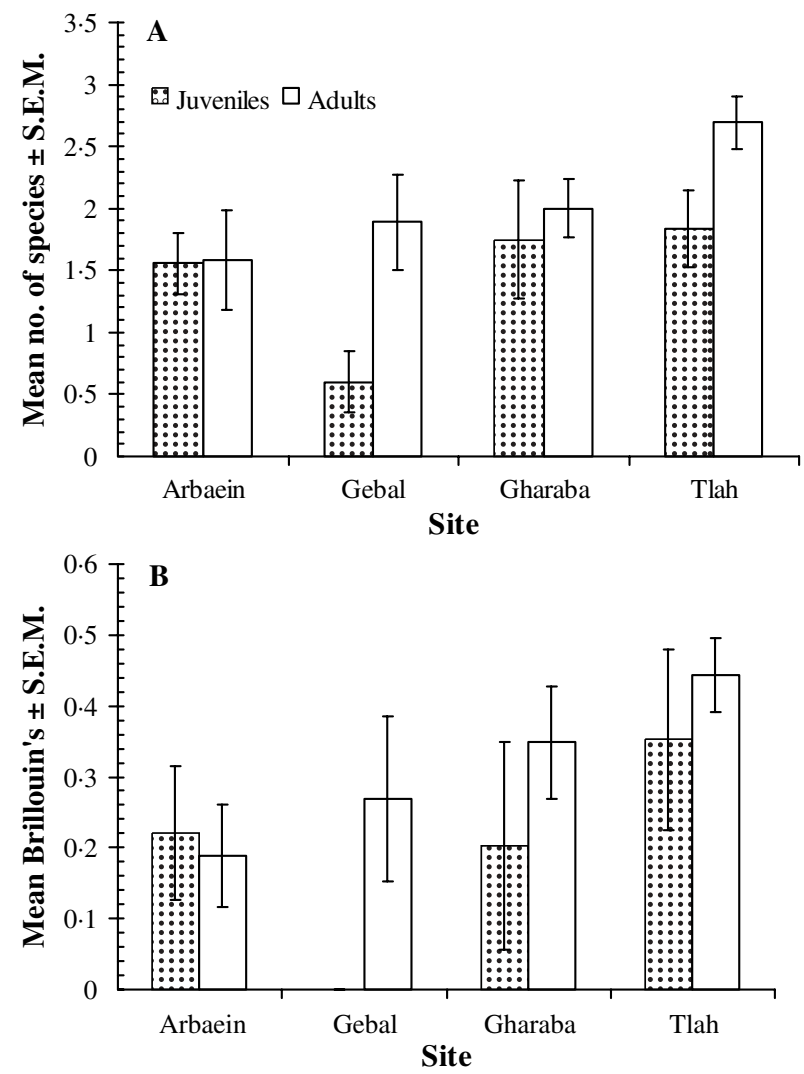

Fig. 3. Age and site dependent variation in mean species richness (A) and Brillouin's Diversity Index (B) based on worm recoveries. For statistical analysis see text.

sites (Table 5, 3-way ANOVA in GLIM with site, sex and age as factors, $\log (x+0 \cdot 1)$ transformed values for Brillouin's index as the dependent variable and normal errors, $F_{3,66}=3 \cdot 95,0 \cdot 025>P>0 \cdot 01$ ), the highest mean value being generated by mice from Wadi Tlah and the lowest by those from Wadi Gebal. There were no other significant terms in this analysis, but the main effect of age was only just outside significance $\left(F_{1,63}=3 \cdot 03,0 \cdot 1>P>0 \cdot 05\right)$ and, as can be seen from Fig. $3 \mathrm{~B}$, the mean value increased with age in mice from three of the wadis, but not in those from Wadi Arbaein (Fig. 3B). Female mice had a higher value compared with males $(0 \cdot 32 \pm 0 \cdot 041$, $0 \cdot 24 \pm 0 \cdot 049$, respectively) but, with age and site taken into consideration, the difference was not significant.
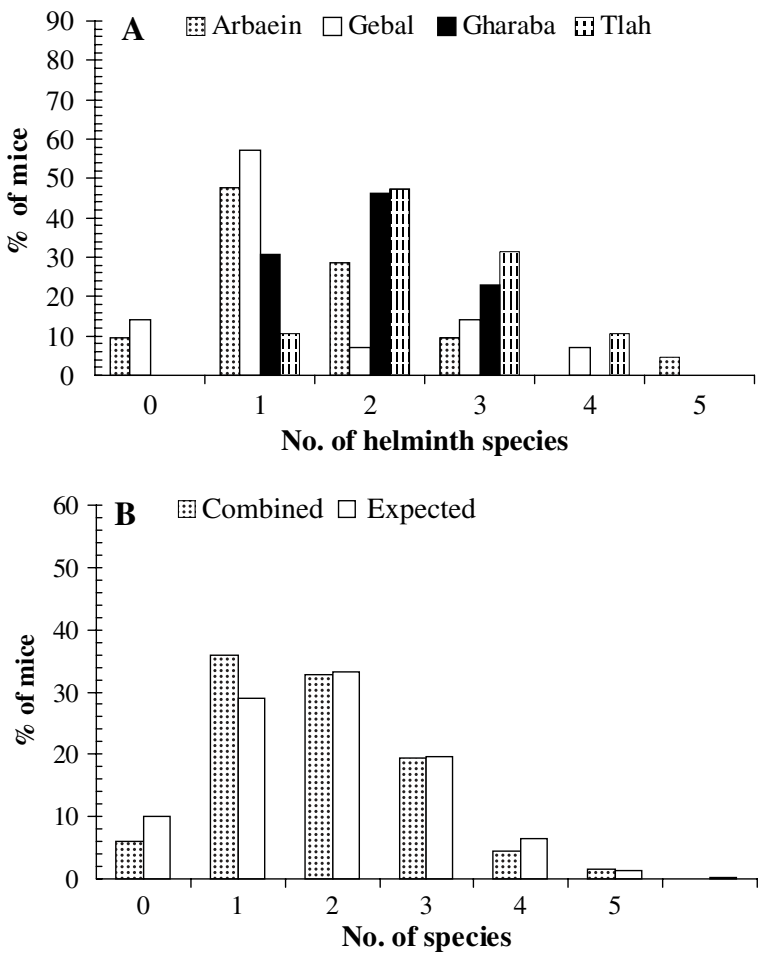

Fig. 4. Frequency distribution of infracommunity species richness for the 4 sites (A) and combined (B), based on worm recoveries. In $\mathrm{B}$, the observed data are in the spotted columns and that predicted by the null model of Janovy et al. (1995) in the open columns. See text for full explanation and statistical analysis.

Species density distributions. The species density distributions at each site are shown in Fig. 4A. As can be seen, the majority of mice in each wadi harboured 1 or 2 species of helminth. In Wadi Arbaein, one mouse harboured 5 species, and in both Wadi Gebal and Wadi Tlah, some mice had 4 helminth species each, but no mice harboured more than 3 helminth species in Wadi Gharaba.

These distributions were adequately described by positive binomial models, but only those for Wadi Arbaein and Wadi Gharaba were compatible with the Poisson distribution. The data from each site were combined (Fig. 4B) and compared to the distribution predicted by the null model for interactions of parasite species in an assemblage (Janovy et al. 
1995). No significant difference was found $\left(\chi^{2}=4 \cdot 9\right.$, D.F. $=3, P=$ N.S. $)$.

Prevalence of species and higher taxa. The prevalence data, based on worms recovered and on faecal egg counts, are summarized by site in Table 3 . At the highest taxonomic level (all helminths combined), and based on worm recovery, there was little difference between the sites. Mice from wadis Gharaba and Tlah showed $100 \%$ prevalence with helminths and those from Arbaein and Gebal $90 \cdot 5 \%$ and $85 \cdot 7 \%$, respectively, and these values did not differ significantly. However, when prevalence was assessed on the basis of positive FEC, the value for Wadi Gharaba was more than twice as high as that for any of the other wadis. This represented a significant difference between wadis (site $\times$ infection interaction $\chi^{2}=17 \cdot 7$, D.F. $\left.=3, P=0 \cdot 0005\right)$.

When the analysis of worm counts was restricted to nematodes (minimum sufficient $\operatorname{model}=$ age + site $\times$ infection, $\chi^{2}=14 \cdot 4,23$ D.F., $\left.P=0 \cdot 915\right)$, prevalence of infection with nematodes varied between sites $\left(\chi^{2}=8 \cdot 6,3\right.$ D.F., $\left.P=0 \cdot 035\right)$ and this was confirmed on the larger data set based on $\operatorname{FEC}\left(\chi^{2}=19 \cdot 8\right.$, D.F. $=3, P=0.0002)$. In both cases, values from Wadi Gharaba were the highest, although prevalence based on worm recovery was also $100 \%$ among mice from Wadi Tlah.

The prevalence of adult strobilate cestodes was low throughout, whether assessed on the basis of worm counts $(10 \cdot 4 \pm 7 \cdot 3 \%)$ or FEC $(6 \cdot 6 \pm 3 \cdot 8 \%)$. In both cases, Wadis El Arbaein and Gebal showed the highest prevalence (Table 3 ). No worms were recovered from the mice from Wadi Gharaba, although one mouse from this wadi passed eggs in its faeces. The difference in prevalence between sites based on FEC was significant $\left(\chi^{2}=17 \cdot 7\right.$, D.F. $\left.=3, P=0 \cdot 0005\right)$, but there was also an independent effect of age $\left(\chi^{2}=24 \cdot 2\right.$, D.F. $\left.=2, P<0 \cdot 0001\right)$, with prevalence increasing from zero in age class 1 , peaking in age class $2(9 \cdot 5 \pm 7 \cdot 2)$ and falling slightly in age class 3 $(7 \cdot 4 \pm 6 \cdot 2)$.

Larval cestodes were only encountered in adult mice (overall prevalence in adults $=9 \cdot 4 \% \pm 8 \cdot 7$ ), and this difference between the age classes was just outside the cut-off for significance $\left(\chi^{2}=3 \cdot 7,1\right.$ D.F., $P=0 \cdot 055)$, but there was no site effect. When larval and adult cestodes were combined, no significant difference was detected.

In total, 4 species of spirurids were recovered, only one of which showed high prevalence overall $(P$. muricola $=47 \cdot 8 \% \pm 12 \cdot 0)$. The minimum sufficient model for $P$. muricola comprised just two interaction terms $\quad\left(\right.$ site $\times$ infection + age $\times$ infection, $\chi^{2}=15 \cdot 5$, 22 D.F., $P=0 \cdot 84$ ). The majority of mice in Wadi Gharaba carried P. muricola (Table 3), although prevalence was also high in Wadi Tlah and Arbaein, contrasting with the absence of this species from Wadi Gebal. This site effect was highly significant $\left(\chi^{2}=31 \cdot 15,3\right.$ D.F., $\left.P<0 \cdot 001\right)$ whilst the independent age effect was relatively weaker $\left(\chi^{2}=5 \cdot 3,1\right.$ D.F., $P=0 \cdot 0212)$, prevalence among adult mice being higher $(58 \cdot 1 \% \pm 14 \cdot 7)$ than among juveniles $(29 \cdot 2 \% \pm 18 \cdot 2)$.

Whilst P. muricola was absent from Wadi Gebal, mice from this wadi showed the highest prevalence of $M$. muris, although prevalence was confounded by an interaction between site and age (the minimum sufficient model $=$ site $\times$ age $\times$ infection, $\chi^{2}=10 \cdot 7$, 16 D.F., $P=0 \cdot 83)$. In Wadis Gebal and Tlah, only adult mice carried $M$. muris $(44 \cdot 4 \% \pm 32 \cdot 5$ and $38 \cdot 5 \% \pm 26 \cdot 4$, respectively); in Wadi Gharaba, it was recovered only from juveniles $(25 \cdot 0 \% \pm 42 \cdot 4)$, whilst in Wadi Arbaein, prevalence was similar among juveniles and adults $(8 \cdot 3 \pm 15 \cdot 6$ and $22 \cdot 2 \pm 27 \cdot 2$, respectively). This 3 -way interaction was a significant term in the model $\left(\chi^{2}=11 \cdot 14,3\right.$ D.F., $\left.P=0 \cdot 011\right)$.

The remaining two species of spirurids, Streptopharagus kuntzi and $S$. numidicus showed much lower overall prevalence $(6 \cdot 0 \% \pm 5 \cdot 7$ and $3 \cdot 0 \% \pm 4 \cdot 1$, respectively) and, interestingly, their occurrence was confined to specific wadis. S. kuntzi was found only in mice from Wadis Arbaein and Tlah, whilst $S$. numidicus was restricted to mice from Wadi Gebal.

The morphology of the eggs of all the spirurid worms in this study was very similar, and it was not easy to distinguish between them. For this reason analysis of FEC was conducted on all spirurid eggs collectively. This confirmed the strong site effect, with prevalence of spirurids in Wadi Gharaba being over twice that in the other wadis (Table $3, \chi^{2}=27 \cdot 8$, D.F. $=3, P<0 \cdot 0001)$. There was also a significant age effect, prevalence increasing consistently from age class 1 to age class $3(2 \cdot 8 \pm 5 \cdot 4,20 \cdot 6 \pm 10 \cdot 0$, $51 \cdot 5 \pm 11.9 \%, \quad$ respectively; $\chi^{2}=24 \cdot 2, \quad$ D.F. $=2$, $P<0 \cdot 0001)$.

None of the directly transmitted oxyuroid nematodes showed significant variation in respect of site or host sex or age, but several of these terms were close to significance. D. kuntzi was the second most important nematode in terms of overall prevalence, occurring in $46.3 \% \pm 11.9$ of the mice. This species did not vary significantly between the wadis, but there was an interesting 3-way interaction that was just outside the cut-off for significance (sex $\times$ age $\times$ infection, $\chi^{2}=3 \cdot 634,1$ D.F., $\left.P=0 \cdot 057\right)$. Among female mice, prevalence was similar in juveniles and adults $(45 \cdot 5 \% \pm 29 \cdot 4$ and $50 \cdot 0 \% \pm 20 \cdot 0$, respectively), but more juvenile males were infected compared with adult males $(69 \cdot 2 \% \pm 25 \cdot 1$ and $26 \cdot 3 \% \pm 19 \cdot 8$, respectively). Very few of the infected mice passed eggs (prevalence based on $\mathrm{FEC}=4 \cdot 2 \pm 3 \cdot 0 \%$ ), and significantly more males did so compared with females $($ males $=7 \cdot 6 \pm 5 \cdot 8 \%$, females $=1 \cdot 1 \pm 2 \cdot 2 \%) \quad\left(\chi^{2}=4 \cdot 7\right.$, D.F. $=1, P=0 \cdot 03)$.

For A. africana, overall prevalence based on worm recovery was $17 \cdot 9 \% \pm 9 \cdot 2 \%$ and that based on FEC 
was lower at $3 \cdot 6 \pm 2 \cdot 8 \%$. The site effect was just outside the cutoff for significance (worm counts, site $\times$ infection, $\chi^{2}=6 \cdot 496,3$ D.F., $\left.P=0 \cdot 09\right)$. For $S$. minuta (overall prevalence based on worm counts $=$ $25 \cdot 4 \% \pm 10 \cdot 4)$, the age effect was close to significance (age $\times$ infection $\chi^{2}=3 \cdot 55,1$ D.F., $P=0 \cdot 06$ ) but no eggs were found in faecal samples.

Frequency distributions and measures of aggregation. The frequency distributions of all species for which quantitative analysis was possible were examined and the summary statistics are given in Table 6. However, it was not possible to fit distributions to all because, in some cases, there were insufficient degrees of freedom arising from too few animals carrying infection. However, of the 19 distributions listed (that for P. muricola in Wadi Gebal is not relevant because none of the mice were infected with this species), 8 did not differ significantly from the negative binomial and 3 from the positive binomial distributions. In 14 cases the value of $D$ exceeded 0.7 suggesting aggregated data, and in 16 cases where it was possible to calculate $I$, the values exceeded 1, also supporting the idea that parasite distributions were aggregated.

Abundance of infection. Table 7 summarizes the mean abundance values for individual species and for higher taxa by site only and based on worm recovery. However, intrinsic factors confounded the data and some of these relationships are illustrated in Fig. 5.

The total helminth burden of mice varied significantly between sites (3-way ANOVA on natural logtransformed data $(x+1)$ and normal errors, for main effect of site $F_{3,65}=6 \cdot 41, P<0 \cdot 001$ ), with mice from Wadi Gharaba carrying the heaviest helminth burdens overall, and those from Wadi Tlah also substantially higher than mice from the other two wadis (Fig. 5A). Mean helminth abundance also increased significantly with host age $\left(F_{1,63}=9 \cdot 53, P<0 \cdot 005\right)$ and this was evident in all four wadis, although the relative increase from juvenile to adult mice was greatest in animals from Wadi Gharaba. A very similar picture emerged when the analysis was confined to just nematodes (main effect of site $F_{3,65}=$ $6.98, P<0.001$; main effect of age $F_{1,63}=8 \cdot 29$, $0 \cdot 01>P>0 \cdot 005)$.

Of 1219 intestinal nematodes recovered in the study, $P$. muricola accounted for $54 \cdot 3 \%$. However, as can be seen from Fig. $5 \mathrm{~B}$, this species was totally absent from mice sampled from Wadi Gebal and maximally abundant in mice from Wadi Gharaba. For this reason, analysis by ANOVA was not possible (variance not uniform between sites, and all attempts to stabilize variance were unsuccessful). Analysis by non-parametric tests confirmed the significance of the site effect (1-way Kruskal-Wallis ANOVA with site as the factor, $\chi^{2}=30 \cdot 1,3$ D.F., $P<0 \cdot 001)$. There was also a significant difference between the age classes (Fig. 5B; Mann-Whitney $U$ test $z=2 \cdot 721, P=0 \cdot 007$ ), with juvenile mice carrying fewer worms compared with adults in the 3 wadis where infected mice were trapped (juveniles $=$ $1 \cdot 0 \pm 0 \cdot 6$, adults $=14 \cdot 8 \pm 4 \cdot 5)$. Despite the higher mean worm burden in female mice (males $=4 \cdot 8 \pm 1 \cdot 9$, females $=14 \cdot 5 \pm 5 \cdot 3)$, there was no significant difference in worm burdens between the sexes. To a large extent, 3 mice that carried 135, 122 and 50 worms respectively generated the high mean in females and when these were excluded, the mean worm burden among the remaining females fell to $6 \cdot 8 \pm 2 \cdot 0$.

Analysis of spirurid FEC supported the strong site and age effects. Fig. 6 shows that FEC were clearly highest in mice from Wadi Gharaba compared to the other three wadis $\left(F_{3,161}=10 \cdot 8, P<0 \cdot 001\right)$, and the age effect was very similar in all four wadis $\left(F_{2,161}=18 \cdot 4, P<0 \cdot 001\right)$, in all cases FEC increasing from the juvenile mice to peak in the oldest animals from each site.

None of the directly transmitted oxyuroid nematodes showed any significant variation in abundance between the sites (Table 7), nor in relation to host sex or age and quantitative analysis of FEC was not possible because of the low prevalence. However, the data in Fig. 5C suggest that, as with prevalence, $D$. kuntzi was concentrated in juvenile mice in Wadis Gebal and Tlah. The apparent higher abundances of S. minuta in Wadi Tlah (Fig. 5D) and in adult mice in Wadi Gebal were all generated by single animals with heavy parasite burdens (37, 50 and 95 worms) in each case. The mean $S$. minuta burden in adult mice was higher than that in juveniles (juveniles= $2 \cdot 4 \pm 1 \cdot 7$, females $=6 \cdot 5 \pm 2 \cdot 7)$ but this difference was just outside significance (Mann-Whitney $U$ test $z=1 \cdot 7, P=0 \cdot 089$ ).

None of the remaining parasites were present in sufficient animals to merit quantitative analysis.

\section{ISCUSSION}

In common with other studies comparing helminth communities of rodents from different sites (Kisielewska, 1970; Montgomery \& Montgomery, 1990; Abu-Madi et al. 1998, 2000; Behnke et al. 2001), differences were found in the helminth community structure of mice from all 4 wadis, each wadi having some unique characteristics. However, the most dramatic finding in the present study was the unexpectedly marked difference in the parasite helminth communities of $A$. dimidiatus from Wadi Gharaba. This was the most distant of our 4 sites, connected to St Katherine by a long route through several other interconnected wadis, including Wadi Tlah. Wadi Gebal was closer to, but nevertheless isolated from St Katherine by high mountain passes. The questions then arise as to whether the locations of these sites were such as to prevent rodents moving between them, thereby limiting gene flow and the 
Table 6. Measures of aggregation for individual species of nematodes by site

\begin{tabular}{|c|c|c|c|c|c|c|c|c|c|c|c|c|}
\hline \multirow[b]{2}{*}{ Species } & \multicolumn{3}{|l|}{ Wadi Arbaein } & \multicolumn{3}{|l|}{ Wadi Gebal } & \multicolumn{3}{|l|}{ Wadi Gharaba } & \multicolumn{3}{|l|}{ Wadi Tlah } \\
\hline & $k^{1}\left( \pm\right.$ S.E.M. $\left.{ }^{4}\right)$ & $I^{2}$ & $D^{3}$ & $k^{1}\left( \pm\right.$ s.E.M. $\left.{ }^{4}\right)$ & $I^{2}$ & $D^{3}$ & $k^{1}\left( \pm\right.$ s.E.M. $\left.{ }^{4}\right)$ & $I^{2}$ & $D^{3}$ & $k^{1}\left( \pm\right.$ s.E.M. $\left.{ }^{4}\right)$ & $I^{2}$ & $D^{3}$ \\
\hline Protospirura muricola & $\begin{array}{l}0 \cdot 120^{7,10,11} \\
(0 \cdot 002)\end{array}$ & $113 \cdot 2$ & $0 \cdot 871$ & $\mathrm{nd}^{5}$ & $\mathrm{nd}^{5}$ & $\mathrm{nd}^{5}$ & $\begin{array}{l}0 \cdot 860^{6,9} \\
(0 \cdot 113)\end{array}$ & $30 \cdot 35$ & $0 \cdot 421$ & $\begin{array}{l}0 \cdot 325^{7,10,11} \\
(0 \cdot 017)\end{array}$ & $11 \cdot 69$ & $0 \cdot 695$ \\
\hline Mastophorus muris & $\begin{array}{l}0 \cdot 146^{6,12,13} \\
(0 \cdot 019)\end{array}$ & $2 \cdot 15$ & $0 \cdot 849$ & $\begin{array}{l}0 \cdot 164^{6,10,12} \\
(0 \cdot 012)\end{array}$ & $4 \cdot 49$ & $0 \cdot 726$ & $\mathrm{nd}^{5}$ & $1 \cdot 00$ & $0 \cdot 857$ & $\begin{array}{l}0 \cdot 213^{6,8} \\
(0 \cdot 021)\end{array}$ & $3 \cdot 29$ & $0 \cdot 779$ \\
\hline Dentostomella kuntzi & $\begin{array}{c}0 \cdot 430^{7,8} \\
(0 \cdot 058)\end{array}$ & $3 \cdot 71$ & 0.696 & $\begin{array}{c}0 \cdot 125^{6,9} \\
(0 \cdot 006)\end{array}$ & $12 \cdot 41$ & $0 \cdot 795$ & $\begin{array}{l}0 \cdot 264^{7,9} \\
(0 \cdot 021)\end{array}$ & $8 \cdot 10$ & 0.668 & $\begin{array}{l}0 \cdot 584^{7,10,12} \\
(0 \cdot 073)\end{array}$ & $4 \cdot 95$ & $0 \cdot 615$ \\
\hline Aspiculuris africana & $\begin{array}{l}0 \cdot 417^{6,9} \\
(0 \cdot 505)\end{array}$ & $1 \cdot 38$ & $0 \cdot 841$ & $\mathrm{nd}^{5}$ & $1 \cdot 00$ & $0 \cdot 867$ & $\mathrm{nd}^{5}$ & $1 \cdot 00$ & $0 \cdot 857$ & $\begin{array}{l}0 \cdot 277^{7,8} \\
(0 \cdot 024)\end{array}$ & $4 \cdot 46$ & $0 \cdot 743$ \\
\hline Syphacia minuta & $\begin{array}{c}0 \cdot 056^{6,8} \\
(0 \cdot 001)\end{array}$ & $9 \cdot 95$ & $0 \cdot 879$ & $\begin{array}{l}0 \cdot 146^{7,10,11} \\
(0 \cdot 005)\end{array}$ & $38 \cdot 03$ & 0.799 & $\begin{array}{l}0 \cdot 047^{6,9} \\
(0 \cdot 001)\end{array}$ & $17 \cdot 94$ & $0 \cdot 850$ & $\begin{array}{l}0 \cdot 085^{7,10,12} \\
(0 \cdot 001)\end{array}$ & $48 \cdot 4$ & $0 \cdot 760$ \\
\hline
\end{tabular}

${ }^{1}$ Negative binomial exponent.

${ }^{2}$ Index of dispersion $=$ Variance to mean ratio.

3 Index of discrepancy (Poulin, 1993).

${ }^{4}$ Standard error of the mean estimate.

5 Not possible to calculate statistic.

${ }^{6}$ Not possible to test for goodness of fit to negative binomial distribution.

7 Not significantly different from negative binomial distribution.

8 Significantly different from positive binomial and Poisson distributions.

${ }^{9}$ Not possible to test for goodness of fit to positive binomial and Poisson distributions.

${ }_{11}^{10}$ Not possible to test for goodness of fit to Poisson distribution.

${ }^{11}$ Significantly different from positive binomial distribution.

${ }^{12}$ Not significantly different from positive binomial distribution.

${ }^{13}$ Not significantly different from Poisson distribution. 
opportunities for exchange of helminth parasites, whether these differences are maintained in the longterm and whether they have consequences for lifehistory strategies of the hosts.

Although $A$. dimidiatus are occasionally observed high on the wadi sides, in our experience they are regularly trapped only on the wadi floors, and often re-trapped within a range of some $100 \mathrm{~m}$, when traps are deployed continuously over periods of about a month in duration. Acomys spp. are believed to be anthropochorous (Gippoliti \& Amori, 2001) and they appear to be sympatric with humans in the Sinai, mostly encountered in the vicinity of Bedouin gardens. However, no information is available on their capacity for longer distance movements or on gene flow between wadis and the relatedness of mice from neighbouring wadis. Studies on insects and plants, however, have provided evidence that the intervening mountains impede gene flow between wadis, and hence each has communities of plants and insects that can be readily distinguished from those of neighbouring wadis at the morphological, behavioural and genetic levels (Gilbert et al. 1996; Wolff, El-Akkad \& Abbot, 1997; Zalat et al. 2001).

Overall, the difference in composition and structure of helminth communities was considerably more marked than reported for bank voles living in ecologically similar sites in Poland (Behnke et al. 2001) and even more marked than the differences found for helminth component communities in wood mice living in three contrasting environments in the UK (Abu-Madi et al. 1998, 2000). In particular, the prevalence of the spirurid nematode $P$. muricola among mice living in Wadi Gharaba was considerably higher and relatively heavy infections were more common than elsewhere. This was evident in worm recoveries, and is also supported by the faecal egg count data, which most likely reflect eggs of $P$. muricola, although other spirurids may have contributed to the total egg count. Not only was prevalence with $P$. muricola high among the mice in Wadi Gharaba, but the worm burdens in some mice were staggering. In our earlier study (Behnke et al. 2000), we recorded a maximum parasite burden with $P$. muricola of 27 worms in one individual from Wadi Abu Seylah, representing $0 \cdot 16 \%$ of body weight, and other mice, whilst carrying fewer larger worms, had worm biomasses representing a range of $0 \cdot 3$ to $0.8 \%$ of host body weight. In the present study, the maximum worm burden was $136(611 \cdot 2 \mathrm{mg}=1 \cdot 36 \%$ of body weight) in a mouse from Wadi El Arbaein, where otherwise infections with this species were much lower. However, the maximum biomass recorded was $2 \cdot 25 \%$ of body weight $(907 \mathrm{mg}$ for 41 worms) in a mouse from Wadi Gharaba, where 5 out of the six heaviest $P$. muricola biomasses (range $1 \cdot 0$ to $2 \cdot 25 \%$ of body weight) were also encountered. Eight mice with infections ranging from 27 to 122 worms all came from Wadi Gharaba. 

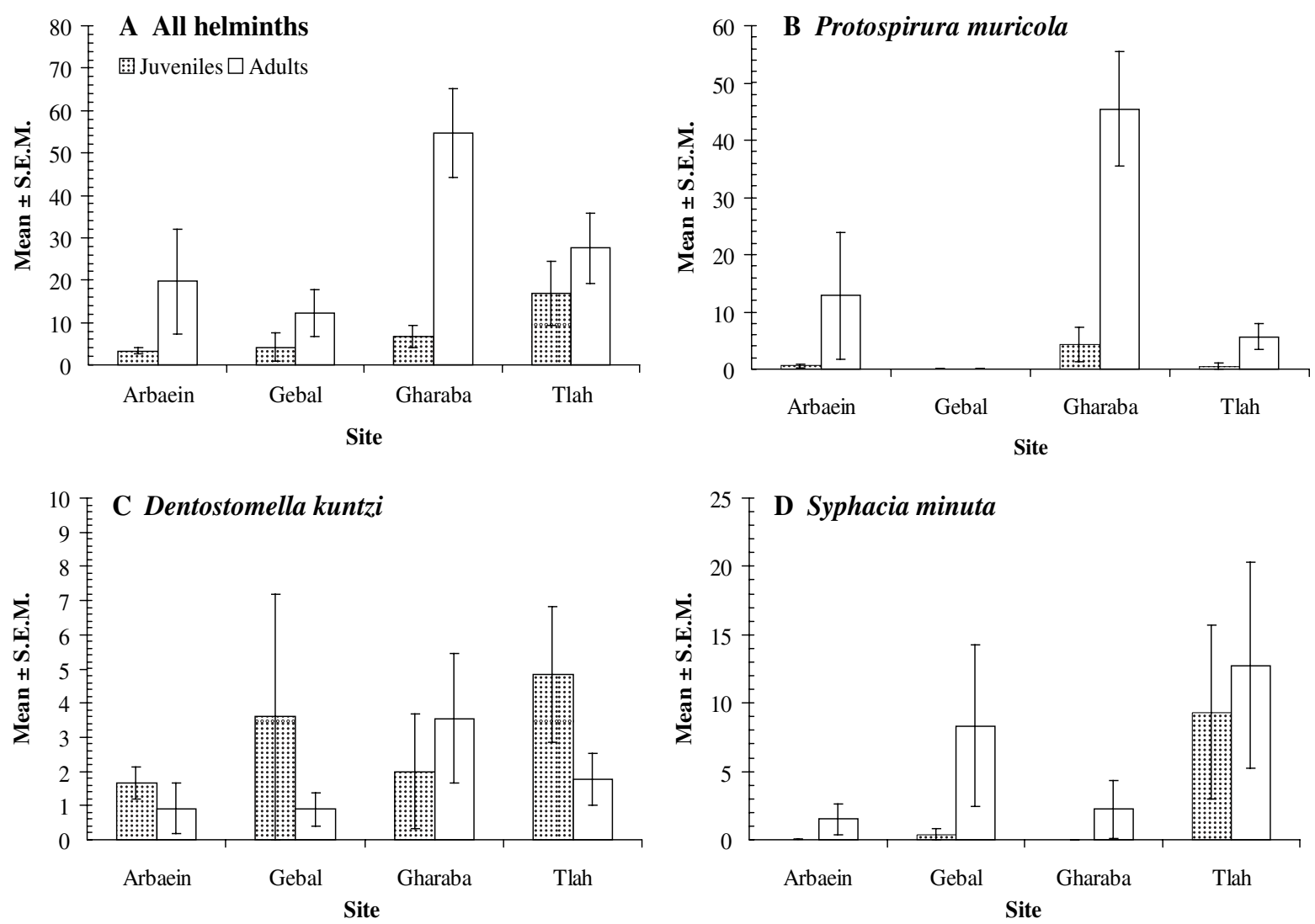

Fig. 5. Quantitative differences in worm burdens between the 4 sites and 2 age classes. (A) All helminths combined. (B) Protospirura muricola. (C) Dentostomella kuntzi. (D) Syphacia minuta.

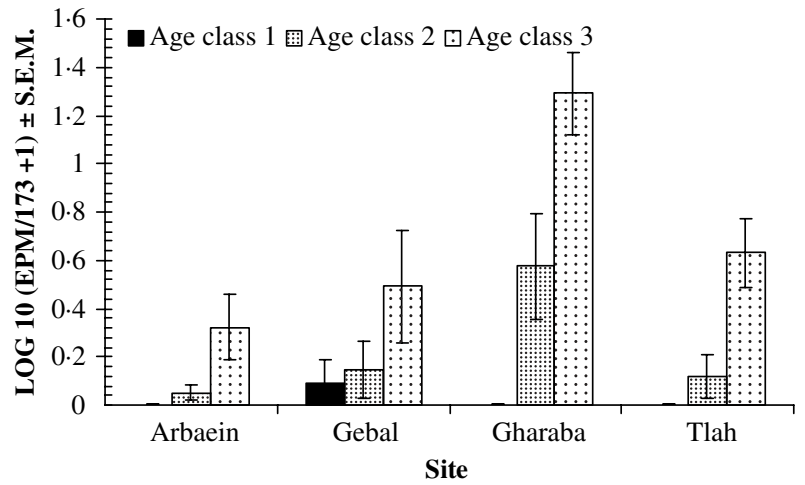

Fig. 6. Site and age-dependent variation in mean faecal concentration of spirurid eggs. The data are presented as mean $\log _{10}(x+1)$ transformed values where $x=$ eggs per $\mathrm{ml}$ of deposit divided by 173 (the lowest egg count), in order to remove discontinuity in the data. The statistical analysis is given in the text and for an explanation of the age classes see Materials and Methods section.

Besides Wadi El Arbaein and Gharaba, P. muricola was also encountered in some mice from Wadi Tlah, but was not found in Wadi Gebal, the highest of the four sites selected for this study, where the stomach niche exploited by $P$. muricola appears to have been occupied by the closely related $M$. muris. Although only one spiny mouse was examined from Wadi Gebal in 1997, it too carried M. muris. Both of these species are transmitted through arthropods in which the infective L3 larvae develop, and although cockroaches of various species are presumed to be involved in transmission, other ground-living insects such as tenebrionid and scarabaeid beetles, may also serve in this capacity (Quentin, 1969, 1970; Campos \& Vargas, 1977; Scharff et al. 1996). In Nottingham, we have successfully maintained a strain of $P$. muricola in Tribolium confusum since 1997 (Behnke, unpublished observations), but which of the locally available species of beetles (Semida et al. 2001) act as hosts in the Sinai is still not known. The recovery of Moniliformis acomysi, only previously reported by Ward \& Nelson (1967), from Wadis El Arbaein and Gharaba suggests that cockroaches exist in the region, and members of the Blattariae have been recorded in insect surveys in the region (Zalat et al. 2001) but, to date, none have been investigated as potential hosts of the two spirurid nematodes. $M$. muris is often found in rodents from temperate northern climatic regions as far north as Poland (Behnke et al. 2001), Alaska (Bangs, 1985) and Finland (Tenora, Henttonen \& Haukisalmi, 1983), although there are records also from warmer climates, e.g. Tel Aviv and Haifa (Wertheim, 1962) and Florida (Kinsella, 1974), whilst P. muricola has been recorded only from tropical parts of the world (e.g. Africa, Quentin, 1969; Scharff et al. 1997). 
The fact that both P. muricola and M. muris occur in the montane wadis of the Sinai is interesting, and the higher prevalence of $P$. muricola at lower altitudes and $M$. muris at higher altitudes is likely to reflect the relative abundance of arthropod intermediate hosts, which presumably are not shared by these two nematodes. A more proximal cause could be the change in temperature with altitude and in this context, it is pertinent to note that the abundance of different flea species varies on spiny mice with altitude (Hoogstraal \& Traub, 1965; Krasnov et al. 2001). Alternatively, the exclusion of P. muricola from the high mountain wadi may be attributable to random extinction events or failure of $P$. muricola to colonize the Wadi Gebal system (Hartvigsen \& Kennedy, 1993). Only 3 mice were found to carry both P. muricola and M. muris ( 2 from Wadi Tlah and 1 from Wadi Gharaba) whereas, on the basis of overall prevalence of each species and the sample size, 6 were expected, and therefore, overall, fewer than expected concurrent infections were detected $\left(\chi^{2}=6 \cdot 1\right.$, D.F. $=2, P=0 \cdot 047$, Janovy et al. 1995). Thus, where they are sympatric, some separation of the species, both of which grow to a considerable size (over $5 \mathrm{~cm}$ and $50 \mathrm{mg}$ for mature female worms for $P$. muricola. See Behnke et al. 2000) and can accumulate to high worm burdens in the stomachs of the hosts, is expected and may reflect the evolutionary outcome of competitive interactions between them in the past (Holmes, 1973; Rohde, 1994). This will form the subject of a separate publication.

As found previously, intestinal nematodes dominated the helminth fauna of these mice $(88.7 \%$ of all helminths recovered) and these were all either arthropod-transmitted species or dependent on direct transmission via eggs. This predominance of arthropod-transmitted nematodes does not support Dobson's hypothesis that xeric hosts should be dominated by monoxenic helminths (Dobson, 1989). Kimberly, Duszynski \& Patrick (2001) also failed to substantiate Dobson's hypothesis in their study of endoparasites of the desert dwelling Dipodomys and Perognathus spp. in New Mexico. On the other hand, in agreement with Dobson (1989), none of the nematodes recorded in the present study, nor that in 1997, were species transmitted by invasive freeliving larvae such as those that dominate small rodent populations in northern regions (e.g. Heligmosomoides polygyrus in Apodemus sylvaticus in the UK, Abu-Madi et al. 1998; Heligmosomum mixtum in Clethrionomys glareolus in Poland, Behnke et al. 2001). Besides the spirurids, and with the exception of a single unidentified larva found in a muscle cyst, the parasite fauna was also represented by Oxyuroids (3 species), which accounted for all the remaining nematode species. None of these species varied significantly between wadis or in relation to host age and sex confirming earlier findings in Acomys (Behnke et al. 2000), and the latter supporting the idea that intrinsic factors are not major determinants of variation in worm burdens among the Oxyuroidea. Similar findings with Syphacia stroma in A. sylvaticus (Abu-Madi et al., 2000) and S. petrusewiczi in C. glareolus (Behnke et al. 2001) have been reported, although Behnke et al. (1999) found a significant increase in the abundance of $S$. stroma with increasing age of wood mice and heavier infections in male versus female mice, when sampling was confined to a single season over several years. Oxyuroid nematodes typically show the most overdispersed infection patterns, because the eggs of Syphacia spp. are immediately infective on emergence on the perianal surface of the host and are easily swallowed by the same host when cleaning itself. The highest worm burden recorded here was 99 , which is similar to the maximum of 77 worms recorded in 1997 in the region, but only a small fraction of the maximum burdens recorded for such species as $S$. petrusewiczi and $S$. stroma that can reach several thousand larval worms per host (Behnke et al. 1999, 2001). These high worm burdens generally conform to the negative binomial distribution but, as in this case, they can be so extreme that analysis by ANOVAs with negative binomial errors is not possible and no suitable transformations can be found to normalize the data.

Among the cestodes, we recorded Foyeuxiella rossicum for the first time from this host, although it has been found in rodents in the former Soviet Union (Tarasovskaya, 1994). This species that has been considered a synonym of $\mathcal{F}$. pasqualei (see Jones, 1983), but the latter, like $\mathcal{F}$. echinorhynchoides, employs lizards as intermediate hosts. If, in this instance, the identity of the intermediate hosts is crucial for separating species then it is safest to conclude that our worms were indeed $\mathcal{F}$. rossicum. This species occurred in one mouse from Wadi Tlah, where we found good evidence of the presence of foxes, the natural definitive hosts of Foyeuxiella spp. Witenbergitaenia sp. has been reported previously from Acomys cahirinus in the Southern Sinai (Wadi Atzvira) and from a vicinity close to Wadi Gebal, the study sites where we found the infected mouse (Wertheim, Schmidt \& Greenberg, 1986). R. nana was recovered from a single mouse in Wadi El Arbaein close to St Katherine where house mice also occur, and may have been the source of the infection whether through intermediate insect hosts or though direct transmission via eggs.

One inescapable conclusion from the analysis presented here is that the parasite helminth communities in $A$. dimidiatus in the wadis around St Katherine were relatively depauperate. Although 13 species of helminths were recorded in 2000 and only 6 in 1997, the average number of helminth species per host was $1 \cdot 8$, a figure very similar to that recorded for helminths of bank voles in Poland (1.44; Behnke et al. 2001) and wood mice in the UK (1.4 and 2.4; Abu-Madi et al. 2000; Behnke et al. 1999). These 
values contrast with considerably higher species richness values recorded from rodents living in other warm climates (Martin \& Huffman, 1980). A possible explanation lies in the nature of the terrain, which is dry, with sparse vegetation and subject to temperatures that range from well below freezing to in excess of $40{ }^{\circ} \mathrm{C}$ in the summer. Under these conditions, the species that are transmitted by free-living larvae are unlikely to be very successful, but many other constraints limiting the range of helminth species available in this remote region of the Peninsula are possible, not the least of which is the scarcity of water and therefore water-transmitted species. Digenean parasites from Acomys were conspicuous by their absence in the present study and those of 1997 and 2001 (Behnke et al. 2000; Barnard et al. $2003 \mathrm{~b}$ ) and, as far as we are aware, no molluscs have been reported from the wadis. However, if the spiny mouse communities in each wadi were truly isolated from others, with minimum gene flow, as on island populations, then founder effects may have contributed to low species richness (de Bellocq, Morand $\&$ Feliu, 2002). Alternatively, because $A$. dimidiatus was probably introduced to the Southern Sinai by humans, the relatively small metapopulation may be unable to sustain a greater species richness (Morand \& Guegan, 2000).

Interestingly, arthropod-transmitted nematodes were much more successful than cestodes, which also rely on insect intermediate hosts and the food chain for transmission. In fact, the prevalence of cestodes in this study, and that of 1997, was much like that experienced in rodents in Europe, although Barnard et al. (2003 b) found prevalence values in 2001 as high as $33 \%$ at exactly the same time of year as the current work and Wertheim \& Greenberg (1970) reported $23.6 \%$ in a year-long study in the Southern Sinai, but both were still considerably lower than the overall prevalence of arthropod-borne nematodes here $(64 \%)$. Two recent studies of rodents from hot arid zones, one of urban rats in Qatar and the other of fat sand rats, Psammomys obesus, in Tunisia, found that cestodes (Hymenolepis diminuta and Raillietina trapezoides, respectively) were the only and major helminth infections, respectively (Abu-Madi et al. 2001; Fichet-Calvet et al. 2003). Therefore, the low prevalence of cestodes in $A$. dimidiatus in the St Katherine region may be unrelated directly to the climatic region as such, but attributable to other factors including abundance of suitable insect intermediate hosts. The contrast in the prevalence of arthropod-transmitted nematodes and cestodes deserved further investigation, including identification of the range of arthropod species that feature regularly in the diet of the mice, since currently nothing is known about potential invertebrate hosts in the region, other than that a range of ground beetles, cockroaches and other potential hosts exist (Semida et al. 2001).
Finally, the results of this study emphasize that helminth communities in small semi-isolated mammal populations may vary considerably between sites. Natural barriers to animal movement, and hence gene flow, can generate foci of high intensity transmission that expose those animals to particular threat of infection. The current study provides a firm basis for further exploration of the consequences of radically different transmission rates of helminths in general, but intestinal spirurids in particular, among con-specific rodents inhabiting different semiisolated patches. The reasons underlying the differences in infection rates between wadis are largely unknown, but they may be attributable to abundance of local arthropod intermediate hosts, key ecological differences between sites or even to host genetics. Genetic variation in rodents is known to be linked to susceptibility/resistance to intestinal nematodes in laboratory systems, and semi-isolated subpopulations of wild rodents are known to differ genetically (Stacy et al. 1994; Gerlach \& Musolf, 2000; Behnke et al. 2003). It will be interesting to test the temporal stability of these differences and to evaluate the relative importance of between-site versus between-year variation in helminth communities in these desert rodents.

We are grateful to the University of Nottingham for the provision of travel expenses and to the British Council, Cairo, Egypt, for financial support for this study. We are grateful to all the staff of the Environment Research Centre of Suez Canal University at St Katherine for their support and warm hospitality during our stay. We thank Mohammed Shaker for permission to work in the St Katherine Protectorate and the staff at the Rangers office for providing vehicles and drivers to enable access to some of the remote locations and for their company and support on each of the expeditions. Mustafa Rashi El-Rafaei's skills in trapping rodents are also gratefully acknowledged. We thank Dr R. Bray from the Natural History Museum in London for advice on the identity of some of the cestodes.

\section{REFERENCES}

ABU-MADI, M. A., BEHNKE, J. M., LEWIS, J. W. \& GILBERT, F. S. (1998). Descriptive epidemiology of Heligmosomoides polygyrus in Apodemus sylvaticus from three contrasting habitats in south-east England. Fournal of Helminthology 72, 93-100.

ABU-MADI, M. A., BEHNKE, J. M., LEWIS, J. W. \& GILBERT, F. S. (2000). Seasonal and site specific variation in the component community structure of intestinal helminths in Apodemus sylvaticus from three contrasting habitats in south-east England. Fournal of Helminthology 74, 7-16.

ABU-MADI, M. A., LEWIS, J. W., MIKHAIL, M., EL-NAGGER, M. E. \& BEHNKE, J. M. (2001). Monospecific helminth and arthropod infections in an urban population of brown rats from Doha, Qatar. Fournal of Helminthology 75, 313-320.

BANGS, E. E. (1985). Occurrence of the nematode Protospirura muris in Alaskan Northern red-backed voles, Clethrionomys rutilus. Canadian Field Naturalist 99, 386-388. 
BARNARD, C. J., BEHNKE, J. M., BAJER, A., BRAY, D., RACE, T., FRAKE, K., OSMOND, J., DINMORE, J. \& SIŃSKI, E. (2002). Local variation in endoparasite intensities of bank voles (Clethrionomys glaroelus) from ecologically similar sites : morphometric and endocrine correlates. Fournal of Helminthology 76, 103-112.

BARNARD, C. J., KULIS, K., BEHNKE, J. M., BAJER, A., GROMADZKA-OSTROWSKA, J., STACHON, M. \& SIŃSKI, E. (2003a). Local variation in helminth burdens of bank voles (Clethrionomys glareolus) from ecologically similar sites: temporal stability and relationships with hormone concentrations and social behaviour. Fournal of Helminthology 77, 185-195.

BARNARD, C. J., SAYED, E., BARNARD, L. E., BEHNKE, J. M., ABDEL NABI, I., SHERIF, N., SHUTT, A. \& ZALAT, S. (2003b). Local variation in helminth burdens of Egyptian spiny mice (Acomys cahirinus dimidiatus) from ecologically similar sites : relationships with hormone concentrations and social behaviour. Fournal of Helminthology 77, 197-207.

BEHNKE, J. M., BARNARD, C. J., BAJER, A., BRAY, D., DINMORE, J., FRAKE, K., OSMOND, J., RACE, T. \& SIŃSKI, E. (2001). Variation in the helminth community structure in bank voles (Clethrionomys glareolus) from three comparable localities in the Mazury Lake District region of Poland. Parasitology 123, 401-414.

BEHNKE, J. M., BARNARD, C. J., MASON, N., HARRIS, P. D., SHERIF, N. E., ZALAT, S. \& GILBERT, F. S. (2000). Intestinal helminths of spiny mice (Acomys cahirinus dimidiatus) from St Katherine's Protectorate in the Sinai, Egypt. Fournal of Helminthology 74, 31-44.

BEHNKE, J. M., IRAQI, F., MENGE, D., BAKER, L., GIBSON, J. \& WAKELIN, D. (2003). Chasing the genes that control resistance to gastrointestinal nematodes. Fournal of Helminthology 77, 99-109.

BEHNKE, J. M., LEWIS, J. W., MOHD ZAIN, S. N. \& GILBERT, F. S. (1999). Helminth infections in Apodemus sylvaticus in southern England: interactive effects of host age, sex and year on the prevalence and abundance of infections. Fournal of Helminthology 73, 31-44.

BROWN, J. S. (1989). Desert rodent community structure: a test of four mechanisms of coexistence. Ecological Monographs 59, 1-20.

BUJALSKA, G. \& HANSSON, L. (Eds) (2000). Bank vole biology: recent advances in the population biology of a model species. Polish Fournal of Ecology 48 (Suppl.), $1-235$.

BUsh, A. O., LAFFerty, K. D., LOTZ, J. M. \& SHOSTAK, A. W. (1997). Parasitology meets ecology on its own terms: Margolis et al., revisited. Fournal of Parasitology 83, 575-583.

CAMPOS, M. Q. \& VARGAS, M. v. (1977). Biologia de Protospirura muricola Gedoelst, 1916 y Mastophorus muris (Gmelin, 1790) (Nematoda: Spiruridae), en Costa Rica. I. Huespedes intermediarios. Revista de Biologia Tropical 25, 191-207.

CHabaud, A. G. (1975). Keys to genera of the Order Spirurida. Part 2. Spiruroidea, Habronematoidea and Acuariodea. In CIH Keys to the Nematode Parasites of Vertebrates (ed. Anderson, R. C., Chabaud, A. G. \& Willmott, S.). Commonwealth Agricultural Bureaux, Slough, UK.

CRAWLEy, M. T. (1993). GLIM for Ecologists. Blackwell Scientific Press, Oxford.
DE BellocQ, J. G., MORAnd, S. \& Feliu, C. (2002). Patterns of parasite species richness of Western Palaearctic micromammals: island effects. Ecography 25, 173-183.

DOBSON, A. P. (1989). Behavioural and life history adaptations of parasites for living in desert environments. Fournal of Arid Environments 17, 185-192.

Elliott, J. M. (1977). Some Methods for the Statistical Analysis of Samples of Benthic Invertebrates. Freshwater Biological Association, Cumbria, UK.

FICHET-CALVET, E., JUEFEI WANG, JOMAA, I., BEN ISMAIL, R. \& ASHFORD, R. W. (2003). Patterns of the tapeworm Raillietina trapezoides infection in the fat sand rat Psammomys obesus in Tunisia: season, climatic conditions, host age and crowding effects. Parasitology 126, 481-492.

FLOWERDEW, J. R., GURNELl, J. \& GIPPS, J. H. W. (Eds) (1985). The Ecology of Woodland Rodents. Bank Voles and Wood Mice. The Zoological Society of London, Clarendon Press, Oxford.

GERlaCH, G. \& MUSOLF, K. (2000). Fragmentation of landscape as a cause for genetic subdivision in bank voles. Conservation Biology 14, 1066-1074.

GILBERT, F., GONZALEZ, A. \& EVANS-FrEkE, I. (1998). Corridors maintain species richness in fragmented landscapes of natural microecosystems. Proceedings of the Royal Society of London, B 265, 577-582.

GILBERT, F., WILLMER, P., SEMIDA, F., GHAZOUL, J. \& ZALAT, s. (1996). Spatial variation in a plant-pollinator system in the wadis of Sinai, Egypt. Oecologia 108, 479-487.

GILBERT, F., ZALAT, s. \& SEMID, A. F. (1999). Insect-plant coevolution in the mountains of Sinai. Egyptian Fournal of Biology 1, 142-151.

GIPPOLiti, s. \& AMOR, G. (2001). Anthropochorous wild mammal taxa and conservation lists. Conservation Biology 16, 1162-1164.

GREENBERG, Z. (1969). Helminths of mammals and birds of Israel. I. Helminths of Acomys spp. (Rodentia, Murinae). Israel Fournal of Zoology 18, 25-38.

HANSKI, I. A. (1997). Metapopulation dynamics: from concepts to predictive models. In Metapopulation Biology: Ecology, Genetics and Evolution (ed. Hanski, I. A. \& Gilpin, M. E.), pp. 69-91. Academic Press, San Diego.

HARTVigsen, R. \& KEnNEDy, C. R. (1993). Patterns in the composition and richness of helminth communities in brown trout, Salmo trutta, in a group of reservoirs. Fournal of Fish Biology 43, 603-615.

HAUKISALMi, v. \& HENTTONEN, H. (2000). Variability of helminth assemblages and populations in the bank vole Clethrionomys glareolus. Polish Zournal of Ecology 48 (Suppl.), 219-231.

Hobbs, J. J. (1995). Mount Sinai. University of Texas Press, Austin, Texas.

HOLMES, J. C. (1973). Site selection by parasitic helminths; interspecific interactions, site segregation, and their importance to the development of helminth communities. Canadian Fournal of Zoology 51, 333-347. HoOgstraAl, H. \& Traub, R. (1965). The fleas

(Siphonaptera) of Egypt. Host-parasite relationships of rodents of the families Spalacidae, Muridae, Gliridae, Dipodidae and Hystricidae. The Fournal of The Egyptian Public Health Association 40, 343-379. 
JANOVY, J. Jr., CLOPTON, R. E., CLOPTON, D. A., SNYDER, S. D., EFTING, A. \& KREBS, L. (1995). Species density distributions as null models for ecologically significant interactions of parasite species in an assemblage. Ecological Modelling 77, 189-196.

JONEs, A. (1983). A revision of the cestode genus Foyeuxiella Fuhrmann, 1935 (Dipelididae: Dipylidiinae). Systematic Parasitology 5, 203-213.

JONES, M. \& DAYAN, T. (2000). Foraging behaviour and microhabitat use by spiny mice, Acomys cahirinus and $A$. russatus, in the presence of Blanford's fox (Vulpes cana) odor. Fournal of Chemical Ecology 26, 455-469.

JONEs, M., MANDELIK, Y. \& DAYAN, T. (2001). Coexistence of temporally partitioned spiny mice: roles of habitat structure and foraging behavior. Ecology 82, 2164-2176.

KENNEDY, C. R. \& HARTVIGSEN, R. A. (2000). Richness and diversity of intestinal metazoan communities in brown trout Salmo trutta compared to those of eels Anguilla anguilla in their European heartlands. Parasitology 121, 55-64.

KIMBERly, H. D., DUSZYNSKI, D. W. \& PATRICK, M. J. (2001). Biotic and abiotic effects on endoparasites infecting Dipodomys and Perognathus species. Fournal of Parasitology 87, 300-307.

KINSElla, J. M. (1974). Comparison of helminth parasites of the cotton rat Sigmodon hispidus, from several habitats in Florida. American Museum Novitates 2540, 1-12.

KISIELEWSKA, K. (1970). Ecological organization of intestinal helminth groupings in Clethrionomys glareolus (Schreb.) (Rodentia). III. Structure of the helminth groupings in $C$. glareolus populations of various forest biocoenoses in Poland. Acta Parasitologica Polonica 18, 163-176.

KOTLER, B. P. \& BROWN, J. S. (1999). Mechanisms of coexistence of optimal foragers as determinants of the local abundances and distributions of desert granivores. Fournal of Mammalogy 80, 361-374.

KRASNOV, B., KHOKHLOVA, I., FIELDEN, R. \& BURDELOVA, N. (2001). The effect of temperature and humidity on the survival of pre-imaginal stages of two flea species (Siphonaptera: Pulicidae). Fournal of Medical Entomology 38, 629-637.

MARGOLIS, L., ESCH, G. W., HOLMES, J. C., KURIS, A. M. \& SCHAD, G. A. (1982). The use of ecological terms in parasitology (report of an ad hoc committee of The American Society of Parasitologists). Fournal of Parasitology 68, 131-133.

MARTIN, J. L. \& HUFFMAN, D. G. (1980). An analysis of the community and population dynamics of the helminths of Sigmodon hispidus (Rodentia: Criceditae) from three central Texas vegetational regions. Proceedings of the Helminthological Society of Washington 47, 247-255.

MONTGOMERY, S. S. J. \& MONTGOMERY, W. I. (1990). Structure, stability and species interactions in helminth communities of wood mice Apodemus sylvaticus. International Fournal for Parasitology 20, 225-242. MOLYNEUX, D. \& ASHFORD, R. W. (1983). The Biology of Trypanosoma and Leishmania, Parasites of Man and Domestic Animals. Taylor \& Francis, London.

MORAND, S. \& GUEGAN, J. F. (2000). Patterns of endemism in host-parasite associations : lessons from epidemiological models and comparative tests. Belgian Fournal of Entomology 2, 135-147.
MORRIS, P. (1972). A review of mammalian age determination methods. Mammal Review 2, 69-104.

POULIN, R. (1993). The disparity between observed and uniform distributions: a new look at parasite aggregation. International Fournal for Parasitology 23, 937-944.

PRICE, M. v. (1986). Structure of desert rodent communities: a critical review of questions and approaches. American Zoologist 26, 39-49.

Quentin, J. C. (1969). Cycle biologique de Protospirura muricola Gedoelst 1916 (Nematoda; Spiruridae). Annales de Parasitologie (Paris) 44, 485-504.

QUENTIN, J. C. (1970). Morphogenese larvarie du spiruride Mastophorus muris (Gmelin, 1790). Annales de Parasitologie (Paris) 45, 839-855.

ROHDE, K. (1994). Niche restriction in parasites: proximate and ultimate causes. Parasitology 109, S69-S84.

ROHLF, F. J. \& SOKAL, R. R. (1995). Statistical Tables. W.H. Freeman and Company, San Francisco.

SCHARFF, A., TENORA, F., KAWALIKA, M., BARUS, V. \& BURDA, H. (1996). Helminths from Zambian mole-rats (Cryptomys spp., Bathyergidae, Rodentia). Helminthologia 33, 105-110.

SCHARFF, A., BURDA, H., TENORA, F., KAWALIKA, M. \& BARUS, v. (1997). Parasites in social subterranean Zambian mole-rats (Cryptomys spp., Bathyergidae, Rodentia). Fournal of Zoology, London 241, 571-577.

SEMIDA, F., ABDEL-DAYEM, M., ZALAT, S. \& GILBERT, F. (2001). Habitat heterogeneity and altitudinal gradients in relation to beetle diversity in South Sinai, Egypt. Egyptian Fournal of Biology 3, 137-146.

SHELdON, B. C. \& VERHulst, s. (1996). Ecological immunology: costly parasite defences and trade-offs in evolutionary ecology. Trends in Ecology and Evolution 11, 317-321.

STACY, J. E., REFSETH, U. H., THORESEN, M., IMS, R. A., stenseth, N. C. \& JAKobsen, K. S. (1994). Genetic variability among root voles (Microtus oeconomus) from different geographical regions: populations can be distinguished by DNA fingerprinting. Biological Fournal of the Linnean Society 52, 273-286.

TARASOVSKAYA, N. E. (1994). On the finding of cysticercoids of Foyeuxiella rossicum (Cestoda: Dipylidiidae) in rodents from Kirgistan. Izvestiya $N A N$ Respubliki Kazakhstan. Serie Biologicheneskaya 6, 20-22. (In Russian.)

TEnora, F., HentTonen, H. \& Haukisalmi, v. (1983). On helminths of rodents in Finland. Annals Zoologica Fennici 20, 37-45.

Thompson, J. N. (1994). The Co-evolutionary Process. University of Chicago Press, Chicago.

WARD, H. L. \& NELSON, D. R. (1967). Acanthocephala of the genus Moniliformis from rodents of Egypt with the description of a new species from Egyptian spiny mouse (Acomys cahirinus). Fournal of Parasitology 53, 150-156.

Washington, H. G. (1984). Diversity, biotic and similarity indices. A review with special relevance to aquatic ecosystems. Water Research 18, 653-694.

WERTHEIM, G. (1962). A study of Mastophorus muris (Gmelin, 1790) (Nematoda: Spiruridae). Transactions of the American Microscopical Society 81, 274-279.

wertheim, G. \& GReEnberG, z. (1970). Notes on helminth parasites of myomorph rodents from Southern Sinai. Fournal of Helminthology 44, 243-252. 
WERTHEIM, G., SCHMIDT, G. D. \& GREENBERG, Z. (1986).

Witenbergitaenia sinaica. N., sp.n. (Anoplocephalidae) and other cestodes from small mammals in Israel and in the Sinai Peninsula. Bulletin du Museum National d'Histoire Naturelle, Paris, 4e serie 8, 543-550.

WILLMER, P., GILBERT, F., GHAZOUL, J., ZALAT, S. \& SEMIDA, F. (1994). A novel form of territoriality: daily paternal investment in an anthrophorid bee. Animal Behaviour 48, 535-549.

WILSON, K. \& GRENFELL, B. T. (1997) Generalized linear modelling for parasitologists. Parasitology Today 13, 33-38.
WOlfF, K., El-AKkad, s. \& ABbotт, R. J. (1997). Population substructure in Alkanna orientalis L. Boiss.

(Boraginaceae) in the Sinai desert, in relation to its pollinator behaviour. Molecular Ecology 6, 194-201.

Zalat, s. \& Gilbert, F. (1998). A walk in Sinai: St.

Katherine to Al Galt Al Azraq (The Blue Pool). El Haramen Press, Cairo, Egypt.

Zalat, S., SEMida, F., GilberT, F., El banNa, S., SAYed, E., EL-ALQAMY, H. \& BEHNKE, J. (2001). Spatial variation in the biodiversity of Bedouin gardens in the St Katherine Protecorate, South Sinai, Egypt. Egyptian Fournal of Biology 3, 147-155. 